GLOBAL JOURNAL OF GEOLOGICAL SCIENCES VOL. 18, 2020: 97-118 COPYRIGHT@ BACHUDO SCIENCE CO. LTD PRINTED IN NIGERIA ISSN 1596-6798

www.globaljournalseries.com, Email: info@globaljournalseries.com

\title{
GEOCHEMICAL EVALUATION OF CAMPANIAN-MAASTRITCHIAN CLAY-SHALE SEDIMENTS OF PATTI FORMATION, SOUTHERN BIDA AND MAMU FORMATION, NORTHERN ANAMBRA BASINS
}

ATABO NATHANIEL ODOMA AND SUNDAY OJOCHOGWU IDAKWO

(Received 19 December 2016; Revision Accepted 20 August 2020)

\begin{abstract}
Two basins (Southern Bida and Northern Anambra Basins) were investigated to deduce weathering, paleooxygenation, provenance, depositional environment and tectonic setting, as well as to establish a relationship between the two basins. The obtained high values of calculated weathering indices such as Chemical index of alteration (CIA > 90), Chemical Index of Weathering ( $\mathrm{CIW}>90)$, Plagioclase Index of Alteration ( $\mathrm{PIA}>90)$ and the $\mathrm{Al}_{2} \mathrm{O}_{3}-(\mathrm{CaO}+$ $\mathrm{Na}_{2} \mathrm{O}$ ) $-\mathrm{K}_{2} \mathrm{O}$ ternary relationship for the clay - shale sediments from both basins indicate intense weathering in the source area. Important geochemical ratios such as $\mathrm{V} / \mathrm{Cr}$, Cu/Zn, Ni/Co, $(\mathrm{Cu}+\mathrm{Mo}) / \mathrm{Zn}$, revealed predominantly oxic conditions for the clay - shale sediments from both basins, although, a more reducing or an anoxic condition cannot be ruled out for the clay - shale sediments from the Southern Bida basin due to high ratios of U/Th (1.93-5.67) and $\mathrm{Cu} / \mathrm{Zn}(0.19-5.00)$. In addition, the Sr/Ba ratios (0.16-3.50) for the clay-shales from the Southern Bida basin indicated an alternated marine and continental paleo-depositional settings and only continental setting $(\mathrm{Sr} / \mathrm{Ba}$ ratios $=0.22-$ 0.50) for the Northern Anambra basin. The Th/Sc, La/Sc, Th/Co and the LREE/HREE ratios showed a derivation of the shale and clay deposits from similar felsic-rich source rock while the log of $\left(\mathrm{K}_{2} \mathrm{O} / \mathrm{Na}_{2} \mathrm{O}\right) \mathrm{vs} \mathrm{SiO}_{2}$, revealed a Passive Margin tectonic setting for the two Basins. There is insignificant differences between the geochemical classifications, weathering, source rock/provenance and tectonic settings of clay-shale sediments of both sedimentary basins, however, there exist slight disparity in their salinity conditions and redox settings.

KEYWORDS: Geochemistry, Clay-shale, Provenance, Tectonic Setting, Northern Anambra and Southern Bida Basins

\section{INTRODUCTION}

Geochemical signatures are crucial for determination of prehistoric and depositional events in rocks. Previous researchers have addressed questions such as depositional environment, provenance, weathering conditions and tectonic settings of the clay-shale deposits in Southern Bida and Northern Anambra Basins of Nigeria (Okunlola and Idowu, 2012; Odoma et al., 2015; Bolarinwa et al., 2019). However, the

relationship between the two basins on the basis of environment of deposition and variation in chemical constituents remain unresolved. Bhatia, 1983; Roser and Korsch, 1986, used distinct ratios like Th/La and $\mathrm{Th} / \mathrm{Sc}$ to discriminate tectonic setting. $\mathrm{TiO}_{2}$ with $\mathrm{La}, \mathrm{Y}$, $\mathrm{Sc}, \mathrm{Cr}$, $\mathrm{Th}, \mathrm{Zr}, \mathrm{Hf}$ and $\mathrm{Nb}$ trace elements in combination are powerful tool for provenance and tectonic setting determination due to their relatively low mobility and they are not significantly redistributed in the course of sedimentation, lithogenesis, and metamorphism
\end{abstract}

Atabo Nathaniel Odoma, Department of Geology, Federal University, Lokoja, kogi State, Nigeria.

Sunday Ojochogwu Idakwo, Department of Geology \& Mining, Ibrahim Badamasi Babangida University, Lapai, Niger State, Nigeria. 
(McLennan et al., 1983; Fatima and Khan, 2012; Zaid, 2012).

A tool that has been used to infer felsic and basic sources in clays and shales from different tectonic environments is the relative distribution of immobile elements such as La, Th Sc, $\mathrm{Cr}$ and Co differing in concentration (Armstrong-Altrin, 2009; Bakkiaraj et al., 2010). La and Th are felsic rock-enriched while Sc, $\mathrm{Cr}$ and Co are enriched in basic rocks (Wronkiewicz and Condie, 1990). Factors that control chemical composition of sedimentary rocks includes: depositional processes, source rocks, weathering, sorting, tectonic setting and paleoclimate (Bhatia, 1983; Wronkiewicz and Condie, 1990; McLennan and Taylor, 1991; McLennan et al., 1993; Armstrong-Altrin, 2009; Bakkiaraj et al., 2010).

Mid-Niger Basin also known as the Bida Basin or the Nupe Basin is a NW-SE trending intracratonic sedimentary basin extending from Kontagora in Niger State of Nigeria to areas slightly beyond Lokoja in the south (Adeleye, 1974; Figs.1 and 2). On the hand, MidSantonian deformation in the Benue Trough displaced the major depositional axis westward which led to the formation of the Anambra Basin. Post-deformational sedimentation in the Lower Benue Trough, led to the formation of the Anambra Basin (Figs. 1 and 2)

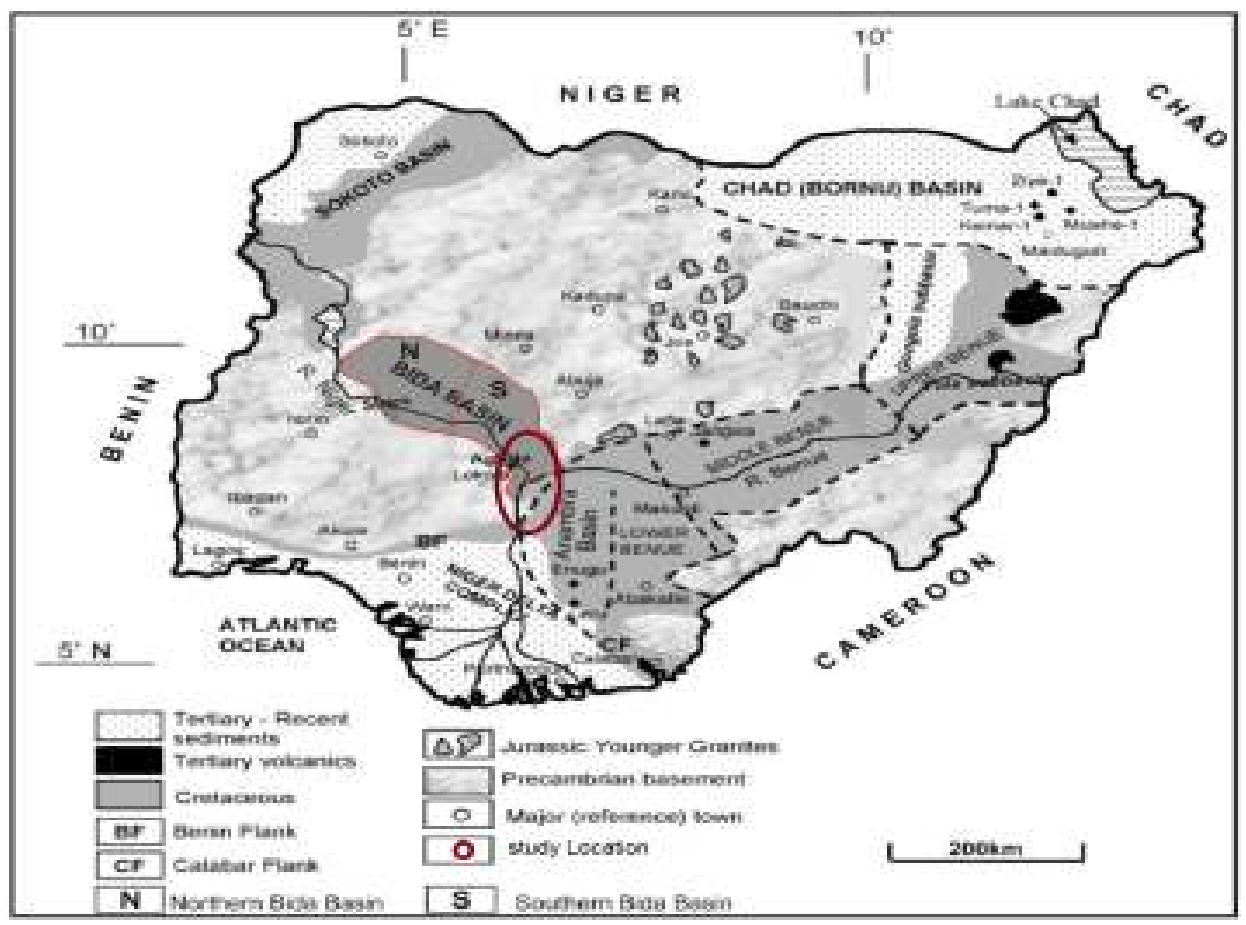

Fig. 1: Geologic Map of Nigeria showing the location of the studied Basins/Area (Modified after Obaje et al., 2004)

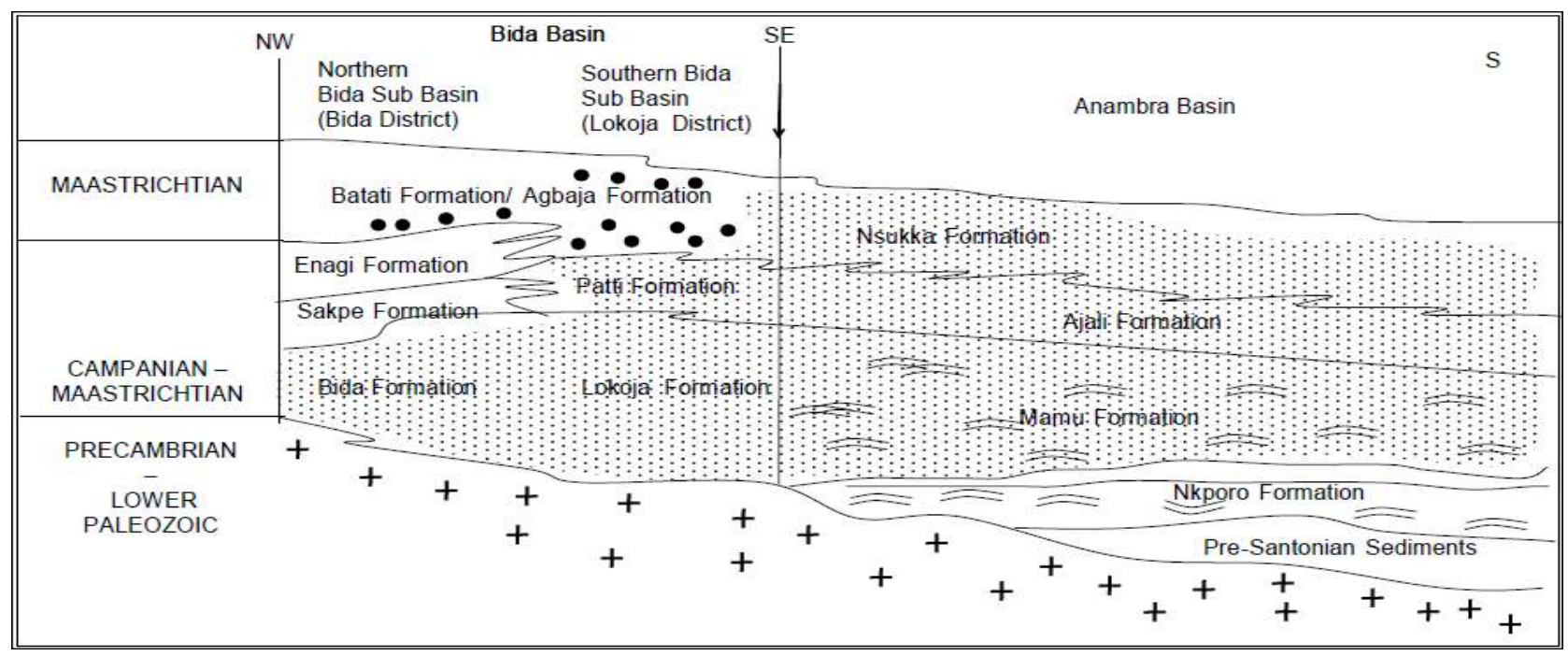

Fig. 2: Geological map showing the Southern Bida and Northern Anambra Basins With sample locations 
Sedimentation in the Anambra Basin thus commenced with the Campanian-Maastrichtian marine and paralic shales of the Enugu and Nkporo Formations, overlain by the coal measures of the Mamu Formation (Obaje, 2009). The Bida Basin is assumed to be a northwesterly extension of the Anambra Basin (Akande et al., 2005). Although, the sedimentary successions of these two basins are lateral equivalents, their geochemical variations, chemical weathering in the source area, provenance, geological and depositional histories are worth studying. They will help to further understand the geology of the two basins, and to compare the two basins based on the clay-shale geochemistry (Overare et al., 2020).

2. GEOLOGY AND STRATIGRAPHY
The origin of the Bida Basin is connected with possibly the Santonian orogenic movements of southeastern Nigeria and the Lower Benue Trough of Nigeria (Ojo and Ajakaiye, 1989). It is a NW-SE basin, which extends from Kontagora, Niger State, Nigeria to slightly beyond Lokoja in the south (Figs. 1, 2 and 3). This basin experienced a northeast and southwest separation by the basement complex but connected with Anambra and Sokoto basins containing post orogenic molasse facies and few thin unfolded marine sediments (Adeleye, 1974). The Bida basin can possibly be regarded as the northwestern extension of the Anambra Basin, with its deposition during the major third transgressive cycle of southern Nigeria at the Late Cretaceous times (Agyingi, 1991).

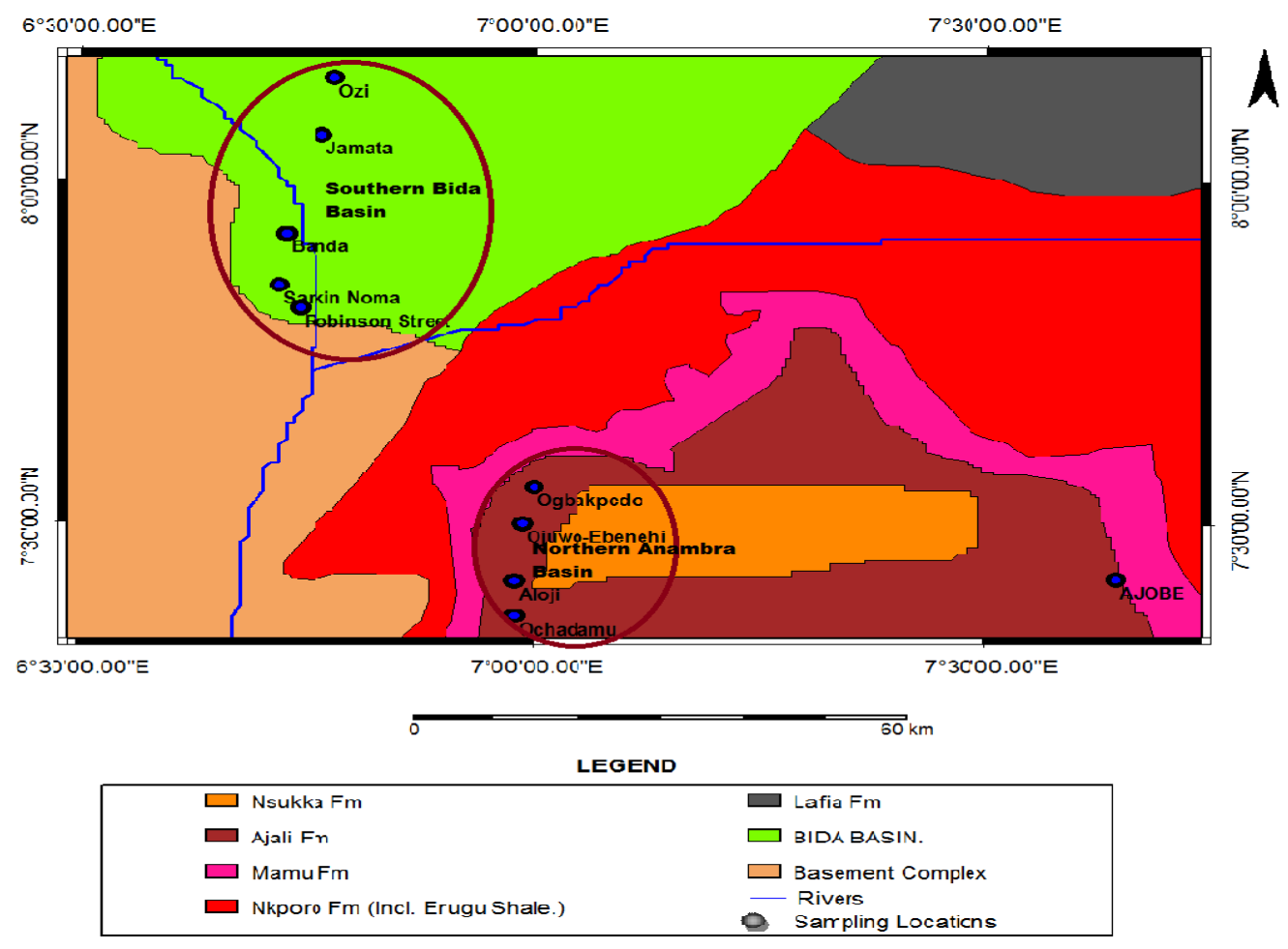

Fig. 3: Stratigraphic successions in the Bida Basin and correlations with adjacent Upper

Cretaceous Succession in Anambra Basin (After Ojo and Akande, 2009) Note, NW = Northwest, SE = Southeast, $\mathrm{S}=$ South,$++=$ Crystalline basement rock

Stratigraphically, the Bida basin is divided into two sectors: the Northern Bida and the Southern Bida basin (Agyingi, 1991).

The Northern Bida basin is made up of Bida sandstone, Sakpe ironstone, Enagi siltstone and Batati ironstone (Fig. 3) while the Southern Bida basin consists of Lokoja sandstone, Patti and Agbaja ironstone Formation (Agyingi, 1991). On the other hand, the Anambra Basin is located in the southeastern part of Nigeria. It is bordered to the north by Bida Basin (Fig. 3), a NE-SW trending, folded, aborted rift basin that runs obliquely across Nigeria (Obaje, 2009; Fig. 3). Hence its origin was linked to the tectonic processes that accompanied the separation of the African and South American plates in the Early Cretaceous (Murat, 1972; Burke et al., 1971).

\section{METHODOLOGY}

Twelve samples (six clay and six shale) were collected from an exposed clay-shale section along Ahoko and Abaji along Lokoja/Abuja highway within the Southern Bida Basin and another twelve samples (six clay and six shale) at Ojodu along Ayingba/ltobe highway within the Mamu Formation in the Northern Anambra Basin. Representative clay and shale samples were collected from different vertical section of the exposures (Figs. 2 and 3) avoiding weathered horizons. Samples were pulverized to $0.07 \mathrm{~mm}$ size for XRD and XRF analyses at Bundesanstalt für Geowissenschaften und Rohstoffe (BGR) Hannover, Germany.

$X R D$ pattern of the representative claystone- shale samples were determined using a PANalytical X'pert PRO MPD diffractometer equipped with a variable divergence slit $(20 \mathrm{~mm}$ irradiated length), primary and secondary soller, scientific X' Celerator detector (Active 
length 0.59), and a sample changer (Sample diameter $28 \mathrm{~mm}$ ). The samples were investigated from 2 to 852 theta with a step size of 0.0167 2theta and a measuring time of $10 \mathrm{~s}$. per step. For the specimen preparation the top loading technique was used

For the XRF analysis, powdered samples were analyzed using a PANalytical Axios. Samples were prepared by mixing a flux material and melting into glass beads. The beads are analyzed by wavelength dispersion X-ray fluorescence spectrometry (WD-XRF) for the following oxides and elements determination; $\mathrm{SiO}_{2}, \mathrm{Al}_{2} \mathrm{O}_{3}, \mathrm{Fe}_{2} \mathrm{O}_{3}$, $\mathrm{CaO}, \mathrm{MgO}, \mathrm{TiO}, \mathrm{P}_{2} \mathrm{O}_{5}, \mathrm{~K}_{2} \mathrm{O}, \mathrm{MnO}$ and LOI, Trace

\section{RESULTS AND DISCUSSION}

The major oxide concentrations, values of plagioclase index of alteration (PIA), chemical index of alteration (CIA) and chemical index of weathering (CIW) as well as calculated geochemical ratios for the studied Cretaceous sediments from Southern Bida and Northern Anambra Basins are presented in Tables 1 and 2. The obtained results were compared to average shales worldwide (Pettijohn, 1957), NASC (Gromet et al., 1984; Turekan and Wedephol, 1961) and shales from other elements such as $\mathrm{As}, \mathrm{Ba}, \mathrm{Co}, \mathrm{Cr}, \mathrm{Cu}, \mathrm{Ga}, \mathrm{Hf}, \mathrm{Nb}, \mathrm{Ni}$, $\mathrm{Pb}, \mathrm{Sr}, \mathrm{Th}, \mathrm{U}, \mathrm{Zr}$ and rare earth elements such as Heavy rare earth elements (HREE) e.g. $Y$ and Sc and Light rare earth elements (LREE) e.g. Ce, La, Nd and Sm. To determine loss on ignition (LOI) $1000 \mathrm{mg}$ of sample material was heated to $1030^{\circ} \mathrm{C}$ for $10 \mathrm{~min}$. after mixing the residue with $5.0 \mathrm{~g}$ lithium metaborate and $25 \mathrm{mg}$ lithium bromide, it is fused at $1200^{\circ} \mathrm{C}$ for $20 \mathrm{~min}$. the calibrations are validated by analysis of Reference materials. Monitor samples and 130 certified reference materials (CRM) are used for the correction procedures.

parts of Nigeria (Tables 3 and 4). The investigated sediments are characterized by high contents of $\mathrm{SiO}_{2}$, moderate $\mathrm{Al}_{2} \mathrm{O}_{3}$, small variation in $\mathrm{Fe}_{2} \mathrm{O}_{3}$ (Tables 1 and 2) but low in $\mathrm{TiO}_{2}, \mathrm{CaO}, \mathrm{Na}_{2} \mathrm{O}$ and $\mathrm{K}_{2} \mathrm{O}$. The low $\mathrm{K}_{2} \mathrm{O}$ values indicated a lack of expandable clays in both sediments, such as montmorillonite (Akpokodje et al., 1991) while the low content of $\mathrm{TiO}_{2}$ and $\mathrm{CaO}$ and $\mathrm{MgO}$ for all the samples is ascribed to strong weathering (Roy et al., 2008).

Table 1: Oxide composition (\%) of clay and shale samples from Southern Bida basin

\begin{tabular}{|c|c|c|c|c|c|c|c|c|c|c|c|c|}
\hline Elements & Abj1.1 & Abj1.2 & Abj1.3 & Abj1.4 & Abj1.5 & Abj1.6 & Abj1.7 & Ahk1.1 & Ahk1.2 & Ahk1.3 & Ahk1.4 & Ahk1.5 \\
\hline $\mathrm{SiO}_{2}$ & 79.20 & 69.33 & 97.02 & 83.84 & 90.13 & 80.05 & 68.62 & 61.62 & 49.69 & 67.94 & 64.12 & 84.57 \\
\hline $\mathrm{Al}_{2} \mathrm{O}_{3}$ & 13.77 & 19.76 & 1.71 & 9.41 & 5.85 & 13.48 & 20.43 & 19.70 & 24.81 & 15.94 & 20.92 & 7.70 \\
\hline $\mathrm{Fe}_{2} \mathrm{O}_{3}$ & 0.69 & 1.47 & 0.13 & 1.11 & 0.57 & 0.62 & 1.58 & 1.56 & 2.91 & 1.41 & 1.63 & 1.57 \\
\hline $\mathrm{MgO}$ & 0.02 & 0.04 & 0.01 & 0.03 & 0.03 & 0.01 & 0.02 & 0.33 & 0.49 & 0.11 & 0.14 & 0.10 \\
\hline $\mathrm{CaO}$ & 0.015 & 0.009 & 0.007 & 0.015 & 0.008 & 0.015 & 0.008 & 0.040 & 0.089 & 0.032 & 0.065 & 0.030 \\
\hline $\mathrm{MnO}$ & 0.006 & 0.006 & 0.002 & 0.003 & 0.006 & 0.003 & 0.003 & 0.048 & 0.059 & 0.022 & 0.034 & 0.015 \\
\hline $\mathrm{Na}_{2} \mathrm{O}$ & 0.01 & 0.01 & 0.01 & 0.01 & 0.01 & 0.01 & 0.01 & 0.04 & 0.10 & 0.05 & 0.04 & 0.03 \\
\hline $\mathrm{K}_{2} \mathrm{O}$ & 0.062 & 0.163 & 0.007 & 0.078 & 0.046 & 0.068 & 0.143 & 0.912 & 0.905 & 1.30 & 1.289 & 0.828 \\
\hline $\mathrm{TiO}_{2}$ & 0.319 & 0.945 & 0.062 & 1.179 & 0.590 & 0.218 & 0.729 & 2.976 & 1.505 & 2.009 & 1.983 & 1.634 \\
\hline $\mathrm{P}_{2} \mathrm{O}_{5}$ & 0.021 & 0.048 & 0.115 & 0.087 & 0.021 & 0.017 & 0.046 & 0.241 & 0.571 & 0.075 & 0.136 & 0.082 \\
\hline LOI & 5.72 & 7.92 & 0.80 & 3.84 & 2.59 & 5.42 & 8.18 & 12.00 & 18.15 & 10.69 & 9.19 & 3.07 \\
\hline Total & 99.84 & 99.68 & 99.85 & 99.60 & 99.85 & 99.87 & 99.75 & 99.45 & 99.25 & 99.49 & 99.55 & 99.62 \\
\hline PIA & 99.78 & 99.9 & 98.84 & 99.68 & 99.66 & 99.78 & 99.9 & 100 & 99.21 & 99.46 & 99.44 & 99.13 \\
\hline CIA & 99.35 & 99.1 & 98.84 & 98.95 & 98.98 & 99.34 & 99.22 & 95.22 & 95.64 & 92.03 & 93.77 & 89.64 \\
\hline CIW & 99.78 & 99.9 & 98.84 & 99.68 & 99.66 & 99.78 & 99.9 & 99.6 & 99.24 & 99.5 & 99.48 & 99.28 \\
\hline $\mathrm{SiO}_{2} / \mathrm{Al}_{2} \mathrm{O}_{3}$ & 5.75 & 3.51 & 56.74 & 8.91 & 15.41 & 5.94 & 3.56 & 3.13 & 2.00 & 4.26 & 3.07 & 10.98 \\
\hline $\mathrm{K}_{2} \mathrm{O} / \mathrm{Na}_{2} \mathrm{O}$ & 6.2 & 16.3 & 0.7 & 7.8 & 4.6 & 6.8 & 14.3 & 22.8 & 9.05 & 26.00 & 32.23 & 27.6 \\
\hline $\mathrm{K}_{2} \mathrm{O} / \mathrm{Al}_{2} \mathrm{O}_{3}$ & 0.09 & 0.01 & 0.004 & 0.01 & 0.01 & 0.01 & 0.01 & 0.05 & 0.04 & 0.08 & 0.06 & 0.11 \\
\hline $\mathrm{Al}_{2} \mathrm{O}_{3 /} \mathrm{TiO}_{2}$ & 43.17 & 20.91 & 27.58 & 7.98 & 9.92 & 61.83 & 28.02 & 21.6 & 16.49 & 7.93 & 10.55 & 4.71 \\
\hline $\mathrm{TiO}_{2} / \mathrm{Al}_{2} \mathrm{O}_{3}$ & 0.02 & 0.05 & 0.04 & 0.13 & 0.10 & 0.02 & 0.04 & 0.15 & 0.06 & 0.13 & 0.09 & 0.21 \\
\hline ICV & 0.06 & 0.09 & 0.10 & 0.13 & 0.11 & 0.05 & 0.09 & 0.15 & 0.18 & 0.18 & 0.15 & 0.33 \\
\hline $\mathrm{D}^{*}$ & 0.95 & 0.93 & 0.93 & 0.89 & 0.91 & 0.96 & 0.93 & 0.92 & 0.89 & 0.92 & 0.93 & 0.83 \\
\hline
\end{tabular}

$D^{*}=\mathrm{Al}_{2} \mathrm{O}_{3} /\left(\mathrm{Al}_{2} \mathrm{O}_{3}+\mathrm{MnO}+\mathrm{Fe}_{2} \mathrm{O}_{3} ;\right.$ Machhour et al., 1994)

*Abj1.1- Abj1.7= Claystone samples *Ahk1.1-Ahk1.5= Shale samples 
Table 2: Oxide composition (\%) of clay and shale samples from Northern Anambra basin

\begin{tabular}{|c|c|c|c|c|c|c|c|c|c|c|c|c|}
\hline & Ojd1.1 & Ojd1.2 & Ojd1.3 & Ojd1.4 & Ojd1.5 & Ojd1.6 & Ojd1.7 & Ojd2.1 & Ojd2.2 & Ojd2.3 & Ojd2.4 & Ojd2.5 \\
\hline $\mathrm{SiO}_{2}$ & 87.31 & 84.39 & 76.99 & 75.47 & 80.39 & 85.83 & 84.35 & 82.42 & 77.86 & 81.51 & 72.99 & 76.03 \\
\hline $\mathrm{Al}_{2} \mathrm{O}_{3}$ & 8.07 & 10.08 & 14.77 & 15.88 & 12.70 & 9.02 & 10.09 & 9.65 & 11.64 & 10.16 & 8.96 & 12.31 \\
\hline $\mathrm{Fe}_{2} \mathrm{O}_{3}$ & 0.26 & 0.34 & 0.66 & 0.53 & 0.47 & 0.29 & 0.33 & 0.76 & 0.84 & 0.70 & 9.37 & 1.31 \\
\hline $\mathrm{MgO}$ & 0.02 & 0.04 & 0.05 & 0.05 & 0.04 & 0.03 & 0.03 & 0.08 & 0.10 & 0.09 & 0.06 & 0.11 \\
\hline $\mathrm{CaO}$ & 0.01 & 0.011 & 0.026 & 0.024 & 0.007 & 0.013 & 0.009 & 0.011 & 0.012 & 0.026 & 0.014 & 0.015 \\
\hline $\mathrm{MnO}$ & 0.003 & 0.005 & 0.005 & 0.005 & 0.004 & 0.005 & 0.004 & 0.006 & 0.009 & 0.022 & 0.105 & 0.011 \\
\hline $\mathrm{Na}_{2} \mathrm{O}$ & 0.01 & 0.01 & 0.02 & 0.02 & 0.01 & 0.01 & 0.01 & 0.03 & 0.02 & 0.01 & 0.01 & 0.04 \\
\hline $\mathrm{K}_{2} \mathrm{O}$ & 0.094 & 0.136 & 0.243 & 0.247 & 0.166 & 0.124 & 0.138 & 0.632 & 0.523 & 0.289 & 0.316 & 0.644 \\
\hline $\mathrm{TiO}_{2}$ & 0.712 & 1.036 & 1.336 & 1.433 & 1.161 & 0.947 & 1.004 & 0.952 & 1.189 & 1.066 & 1.055 & 1.480 \\
\hline $\mathrm{P}_{2} \mathrm{O}_{5}$ & 0.026 & 0.037 & 0.047 & 0.040 & 0.030 & 0.035 & 0.034 & 0.040 & 0.049 & 0.053 & 0.054 & 0.058 \\
\hline LOI & 3.32 & 3.68 & 5.63 & 6.07 & 4.83 & 3.49 & 3.81 & 5.21 & 7.49 & 5.78 & 6.80 & 7.71 \\
\hline Total & 99.85 & 99.79 & 99.77 & 99.76 & 99.78 & 99.80 & 99.77 & 99.79 & 99.71 & 99.71 & 99.69 & 99.67 \\
\hline PIA & 97.56 & 99.80 & 99.66 & 96.66 & 97.21 & 98.45 & 97.17 & 87.32 & 91.22 & 94.10 & 92.90 & 89.70 \\
\hline CIA & 98.66 & 98.44 & 98.07 & 98.07 & 98.21 & 98.6 & 98.36 & 98.44 & 93.51 & 95.41 & 96.85 & 94.62 \\
\hline CIW & 99.75 & 99.8 & 99.66 & 99.75 & 99.84 & 99.78 & 99.80 & 99.59 & 99.74 & 99.61 & 99.78 & 99.51 \\
\hline $\mathrm{SiO}_{2} / \mathrm{Al}_{2} \mathrm{O}_{3}$ & 10.82 & 8.37 & 5.21 & 4.75 & 6.33 & 9.52 & 8.36 & 8.54 & 6.69 & 8.02 & 8.15 & 6.18 \\
\hline $\mathrm{K}_{2} \mathrm{O} / \mathrm{Na}_{2} \mathrm{O}$ & 9.4 & 13.6 & 12.5 & 12.35 & 16.6 & 12.4 & 13.8 & 21.07 & 26.15 & 28.9 & 31.6 & 16.1 \\
\hline $\mathrm{K}_{2} \mathrm{O} / \mathrm{Al}_{2} \mathrm{O}_{3}$ & 0.01 & 0.01 & 0.02 & 0.02 & 0.01 & 0.01 & 0.01 & 0.07 & 0.04 & 0.03 & 0.04 & 0.05 \\
\hline $\mathrm{Al}_{2} \mathrm{O}_{3} / \mathrm{TiO}_{2}$ & 11.33 & 9.73 & 11.06 & 11.08 & 10.94 & 9.52 & 10.05 & 10.14 & 9.79 & 9.53 & 8.49 & 8.31 \\
\hline $\mathrm{TiO}_{2} / \mathrm{Al}_{2} \mathrm{O}_{3}$ & 0.09 & 0.10 & 0.09 & 0.09 & 0.90 & 0.10 & 0.10 & 0.10 & 0.10 & 0.11 & 0.12 & 0.12 \\
\hline $\mathrm{ICV}$ & 0.05 & 0.05 & 0.07 & 0.06 & 0.05 & 0.05 & 0.05 & 0.16 & 0.13 & 0.11 & 1.10 & 0.17 \\
\hline$D^{*}$ & 0.97 & 0.97 & 0.96 & 0.97 & 0.96 & 0.97 & 0.97 & 0.93 & 0.93 & 0.93 & 0.49 & 0.90 \\
\hline
\end{tabular}

$D^{*}=\mathrm{Al}_{2} \mathrm{O}_{3} /\left(\mathrm{Al}_{2} \mathrm{O}_{3}+\mathrm{MnO}+\mathrm{Fe}_{2} \mathrm{O}_{3} ;\right.$ Machhour et al., 1994)

*Ojd1.1-Ojd1.7= Claystone samples $\quad$ *Ojd2.1-Ojd2.5= Shale samples

Table 3: Average chemical composition of southern Bida and northern Anambra claystone and shale compared to shale from other sedimentary basins in Nigeria

\begin{tabular}{|c|c|c|c|c|c|c|c|c|}
\hline \multirow[t]{2}{*}{ Oxides } & \multicolumn{2}{|c|}{ Claystone $^{1}$} & \multicolumn{2}{|c|}{ Shale $^{1}$} & \multirow{2}{*}{$\begin{array}{l}\text { Asu River } \\
\text { group } \\
\text { (Amajor,1987) }\end{array}$} & \multirow{2}{*}{$\begin{array}{l}\text { Ezeaku shale } \\
\text { (Amajor,1987) }\end{array}$} & \multirow{2}{*}{$\begin{array}{l}\text { Auchi } \\
\text { shale }\end{array}$} & \multirow{2}{*}{$\begin{array}{l}\text { Ifon Shale } \\
\text { Ajayi et al, } \\
\text { 1989) }\end{array}$} \\
\hline & SBB & NAB & SBB & NAB & & & & \\
\hline $\mathrm{SiO}_{2}$ & 81.17 & 82.10 & 65.59 & 78.16 & 69.94 & 44.91 & 51.68 & 63.30 \\
\hline $\mathrm{TiO}_{2}$ & 0.58 & 1.09 & 2.02 & 1.15 & 0.52 & 0.65 & 1.95 & 1.02 \\
\hline $\mathrm{Al}_{2} \mathrm{O}_{3}$ & 12.06 & 11.52 & 17.81 & 10.54 & 10.00 & 15.71 & 18.76 & 18.47 \\
\hline $\mathrm{Fe}_{2} \mathrm{O}_{3}$ & 0.88 & 0.41 & 1.82 & 2.60 & 4.04 & 6.24 & 4.67 & 1.26 \\
\hline $\mathrm{MnO}$ & 0.004 & 0.004 & 0.04 & 0.03 & 0.04 & 0.06 & 0.06 & 0.01 \\
\hline $\mathrm{MgO}$ & 0.02 & 0.04 & 0.23 & 0.09 & 0.87 & 2.58 & 4.39 & 0.82 \\
\hline $\mathrm{CaO}$ & 0.01 & 0.01 & 0.05 & 0.02 & 3.38 & 15.42 & 1.90 & 0.09 \\
\hline $\mathrm{Na}_{2} \mathrm{O}$ & 0.01 & 0.01 & 0.05 & 0.02 & 0.40 & 0.42 & 0.93 & 0.42 \\
\hline $\mathrm{K}_{2} \mathrm{O}$ & 0.08 & 0.16 & 1.05 & 0.48 & 1.15 & 2.36 & 1.16 & 2.36 \\
\hline $\mathrm{P}_{2} \mathrm{O}_{5}$ & 0.05 & 0.04 & 0.22 & 0.05 & 0.17 & 0.46 & 0.25 & 0.46 \\
\hline LOI & 4.92 & 4.40 & 10.62 & 6.60 & 9.21 & 11.1 & 14.05 & 11.6 \\
\hline Total & 99.78 & 99.78 & 99.50 & 99.74 & 99.69 & 99.91 & 99.87 & 99.81 \\
\hline
\end{tabular}

${ }^{1}$ Present study, SBB $=$ Southern Bida Basin, NAB= Northern Anambra Basin 
Table 4: Comparing average chemical composition of the southern bida and northern anambra claystone shale studied here to published average shales

\begin{tabular}{|c|c|c|c|c|c|c|c|c|}
\hline \multirow[t]{2}{*}{ Oxides } & \multirow[t]{2}{*}{ Claystone $^{T}$} & \multicolumn{3}{|c|}{ Shale $^{1}$} & \multirow{2}{*}{$\begin{array}{l}\text { Average } \\
\text { shale } \\
\text { (Pettijohn, } \\
1957 \text { ) }\end{array}$} & \multirow{2}{*}{$\begin{array}{l}\text { Turekan \& } \\
\text { Wedephol } \\
\text { (1961) }\end{array}$} & \multirow[t]{2}{*}{ PAAS } & \multirow{2}{*}{$\begin{array}{l}\text { NASC } \\
\text { (Gromet et } \\
\text { al., 1984) }\end{array}$} \\
\hline & & NAB & SBB & NAB & & & & \\
\hline $\mathrm{SiO}_{2}$ & 81.17 & 82.10 & 65.59 & 78.16 & 58.10 & 58.50 & 62.40 & 64.82 \\
\hline $\mathrm{TiO}_{2}$ & 0.58 & 1.09 & 2.02 & 1.15 & 0.60 & 0.77 & 0.99 & 0.80 \\
\hline $\mathrm{Al}_{2} \mathrm{O}_{3}$ & 12.06 & 11.52 & 17.81 & 10.54 & $15 . .40$ & 15.00 & 18.78 & 17.05 \\
\hline $\mathrm{Fe}_{2} \mathrm{O}_{3}$ & 0.88 & 0.41 & 1.82 & 2.60 & 6.90 & 4.72 & 7.18 & 5.70 \\
\hline $\mathrm{MnO}$ & 0.004 & 0.004 & 0.04 & 0.03 & Trace & - & - & - \\
\hline $\mathrm{MgO}$ & 0.02 & 0.04 & 0.23 & 0.09 & 2.40 & 2.50 & 2.19 & 2.83 \\
\hline $\mathrm{CaO}$ & 0.01 & 0.01 & 0.05 & 0.02 & 3.10 & 3.10 & 1.29 & 3.51 \\
\hline $\mathrm{Na}_{2} \mathrm{O}$ & 0.01 & 0.01 & 0.05 & 0.02 & 1.30 & 1.30 & 1.19 & 1.13 \\
\hline $\mathrm{K}_{2} \mathrm{O}$ & 0.08 & 0.16 & 1.05 & 0.48 & 3.20 & 3.10 & 3.68 & 3.97 \\
\hline $\mathrm{P}_{2} \mathrm{O}_{5}$ & 0.05 & 0.04 & 0.22 & 0.05 & 0.20 & 0.16 & 0.16 & 0.15 \\
\hline
\end{tabular}

${ }^{1}$ Present study, $\mathrm{SBB}=$ Southern Bida Basin, $\mathrm{NAB}=$ Northern Anambra Basin

The interrelationships between major oxides, some trace and rare elements are given in Tables 5 and 6.

The abundance of silica and alumina are attributed to the clayey-silty nature of the samples as well as presence of biogenic $\mathrm{SiO}_{2}$ as indicated by the $\mathrm{SiO}_{2-}$ $\mathrm{Al}_{2} \mathrm{O}_{3}$ association (Fig. 4A). The observed strong negative correlation between $\mathrm{SiO}_{2}$ and $\mathrm{Al}_{2} \mathrm{O}_{3} ; \mathrm{r}=-0.96$ (Table 5) and $r=-0.58$ (Table 6) for the sediments from Southern Bida Basin and Northern Anambra Basin respectively, suggest a terrigenous origin for the studied sediments (Moosavirada et al., 2011). This is also supported by the $\mathrm{Fe}_{2} \mathrm{O}_{3} / \mathrm{TiO}_{2}$ vs. $\mathrm{Al}_{2} \mathrm{O}_{3} /\left(\mathrm{Al}_{2} \mathrm{O}_{3}+\mathrm{Fe}_{2} \mathrm{O}_{3}+\mathrm{MnO}\right)$ diagram (Fig. 4B) where the investigated clay-shale sediments plot near the terrigenous end-member around PAAS and UCC.

On the other hand, $\mathrm{Al}_{2} \mathrm{O}_{3}$ and $\mathrm{Fe}_{2} \mathrm{O}_{3}$ show significant positive correlation value $(r=0.79$, Table 5$)$ in the samples from the Southern Bida Basin, signifying a representative of detrital input into the the basin (Mishra et al., 2019). In contrast, the Northern Anambra Basin, showed negative correlation for $\mathrm{Al}_{2} \mathrm{O}_{3}$ and $\mathrm{Fe}_{2} \mathrm{O}_{3}(r=-$ 0.24 , Table 6 ), this could be attributed to lack of $\mathrm{Fe}$ oxides in the Northern Anambra Basin. This is true as ironstone of Agbaja Formation is associated with the Southern Bida basin as documented by Adeleye and Dessauvagie (1972).

Table 5: Pearson's Correlation coefficients of major and trace elements for the investigated Cretaceous sediment of Southern Bida Basin

\begin{tabular}{|c|c|c|c|c|c|c|c|c|c|c|c|c|c|c|c|}
\hline & $\mathrm{Al}_{2} \mathrm{O}_{3}$ & $\mathrm{Ba}$ & $\mathrm{CaO}$ & $\mathrm{Co}$ & $\mathrm{Fe}_{2} \mathrm{O}_{3}$ & $\mathrm{~K} 2 \mathrm{O}$ & $\mathrm{La}$ & $\mathrm{MgO}$ & $\mathrm{Na}_{2} \mathrm{O}$ & $\mathrm{Ni}$ & $\mathrm{SiO}_{2}$ & $\mathrm{Sr}$ & Th & $\mathrm{TiO}_{2}$ & V \\
\hline $\mathrm{Al}_{2} \mathrm{O}_{3}$ & 1 & & & & & & & & & & & & & & \\
\hline $\mathrm{Ba}$ & 0.5664 & 1 & & & & & & & & & & & & & \\
\hline $\mathrm{CaO}$ & 0.5643 & 0.9407 & 1 & & & & & & & & & & & & \\
\hline Co & 0.615 & 0.9663 & 0.9157 & 1 & & & & & & & & & & & \\
\hline $\mathrm{Fe}_{2} \mathrm{O}_{3}$ & 0.7888 & 0.7994 & 0.7998 & 0.768 & 1 & & & & & & & & & & \\
\hline $\mathrm{K}_{2} \mathrm{O}$ & 0.4848 & 0.5467 & 0.6913 & 0.6478 & 0.6288 & 1 & & & & & & & & & \\
\hline $\mathrm{La}$ & 0.5112 & 0.1693 & 0.1607 & 0.1417 & 0.4964 & 0.2683 & 1 & & & & & & & & \\
\hline $\mathrm{MgO}$ & 0.596 & 0.9761 & 0.9016 & 0.985 & 0.8003 & 0.6119 & 0.1603 & 1 & & & & & & & \\
\hline $\mathrm{Na}_{2} \mathrm{O}$ & 0.5668 & 0.945 & 0.987 & 0.9284 & 0.8228 & 0.7355 & 0.1662 & 0.9156 & 1 & & & & & & \\
\hline $\mathrm{Ni}$ & 0.615 & 0.9663 & 0.9157 & 1 & 0.768 & 0.6478 & 0.1417 & 0.985 & 0.9284 & 1 & & & & & \\
\hline $\mathrm{SiO}_{2}$ & -0.9642 & -0.7373 & -0.7404 & -0.7895 & -0.8757 & -0.6301 & -0.4615 & -0.767 & -0.7494 & -0.7895 & 1 & & & & \\
\hline $\mathrm{Sr}$ & 0.26 & 0.8842 & 0.756 & 0.7958 & 0.5294 & 0.2335 & 0.0732 & 0.808 & 0.7603 & 0.7958 & -0.4286 & 1 & & & \\
\hline Th & 0.4428 & 0.2499 & 0.3307 & 0.2967 & 0.5964 & 0.5852 & 0.7773 & 0.3092 & 0.3424 & 0.2967 & -0.4936 & -0.0231 & 1 & & \\
\hline $\mathrm{TiO}_{2}$ & 0.4859 & 0.506 & 0.5274 & 0.6539 & 0.609 & 0.8383 & 0.36 & 0.6436 & 0.5696 & 0.6539 & -0.6221 & 0.1917 & 0.7203 & 1 & \\
\hline $\mathrm{V}$ & 0.6991 & 0.695 & 0.7181 & 0.8109 & 0.8084 & 0.8435 & 0.3493 & 0.7811 & 0.7641 & 0.8109 & -0.8331 & 0.3723 & 0.6444 & 0.9131 & 1 \\
\hline $\mathrm{Zr}$ & 0.0805 & -0.1133 & 0.061 & -0.0603 & 0.2932 & 0.5345 & 0.5266 & -0.0489 & 0.0779 & -0.0603 & -0.1207 & -0.3475 & 0.8432 & 0.5715 & 0.4078 \\
\hline
\end{tabular}


Table 6: Pearson's Correlation coefficients of major and trace elements for the investigated Cretaceous sediments of the Northern Anambra Basin

\begin{tabular}{|c|c|c|c|c|c|c|c|c|c|c|c|c|c|c|c|}
\hline & $\mathrm{Al}_{2} \mathrm{O}_{3}$ & $\mathrm{Ba}$ & $\mathrm{CaO}$ & Co & $\mathrm{Fe}_{2} \mathrm{O}_{3}$ & $\mathrm{~K}_{2} \mathrm{O}$ & $\mathrm{La}$ & $\mathrm{MgO}$ & $\mathrm{Na}_{2} \mathrm{O}$ & $\mathrm{Ni}$ & $\mathrm{SiO}_{2}$ & $\mathrm{Sr}$ & Th & $\mathrm{TiO}_{2}$ & V \\
\hline $\mathrm{Al}_{2} \mathrm{O}_{3}$ & 1 & & & & & & & & & & & & & & \\
\hline $\mathrm{Ba}$ & 0.2067 & 1 & & & & & & & & & & & & & \\
\hline $\mathrm{CaO}$ & 0.5389 & 0.3388 & 1 & & & & & & & & & & & & \\
\hline Co & -0.2368 & 0.1526 & -0.0796 & 1 & & & & & & & & & & & \\
\hline $\mathrm{Fe}_{2} \mathrm{O}_{3}$ & -0.2413 & 0.0744 & -0.1505 & 0.9884 & 1 & & & & & & & & & & \\
\hline $\mathrm{K}_{2} \mathrm{O}$ & 0.1322 & 0.9257 & 0.1016 & 0.2104 & 0.1427 & 1 & & & & & & & & & \\
\hline $\mathrm{La}$ & 0.6971 & 0.4343 & 0.4739 & 0.1575 & 0.1194 & 0.3264 & 1 & & & & & & & & \\
\hline $\mathrm{MgO}$ & 0.1811 & 0.9546 & 0.3442 & 0.1946 & 0.1251 & 0.8939 & 0.4521 & 1 & & & & & & & \\
\hline $\mathrm{Na}_{2} \mathrm{O}$ & 0.3694 & 0.8326 & 0.2315 & 0.0602 & -0.1119 & 0.8575 & 0.342 & 0.6919 & 1 & & & & & & \\
\hline $\mathrm{Ni}$ & 0.1299 & 0.3896 & 0.2056 & $\begin{array}{l}0.8948 \\
-\end{array}$ & 0.8835 & $\begin{array}{l}0.3813 \\
-\end{array}$ & 0.4609 & $\begin{array}{l}0.4526 \\
-\end{array}$ & 0.1573 & $\begin{array}{l}1 \\
-\end{array}$ & & & & & \\
\hline $\mathrm{SiO}_{2}$ & -0.5872 & -0.5007 & -0.3553 & 0.5947 & -0.5821 & 0.4837 & -0.7135 & 0.5327 & -0.4124 & 0.8611 & 1 & & & & \\
\hline $\mathrm{Sr}$ & 0.0397 & 0.9243 & 0.3401 & 0.4309 & 0.3556 & $\begin{array}{l}0.851 \\
-\end{array}$ & 0.4262 & $\begin{array}{l}0.9502 \\
-\end{array}$ & 0.6326 & 0.6151 & $\begin{array}{l}-0.582 \\
-\end{array}$ & 1 & & & \\
\hline Th & 0.4121 & -0.2783 & 0.1865 & 0.3306 & 0.3788 & 0.3779 & 0.5215 & 0.2133 & -0.3022 & 0.427 & $\begin{array}{l}0.4975 \\
-\end{array}$ & -0.139 & 1 & & \\
\hline $\mathrm{TiO}_{2}$ & 0.8658 & 0.5318 & 0.5384 & 0.011 & -0.0018 & 0.4114 & 0.765 & 0.5045 & 0.5787 & 0.3886 & 0.7696 & 0.4274 & 0.438 & 1 & \\
\hline V & 0.7219 & 0.5925 & 0.7437 & 0.0246 & -0.0374 & 0.4418 & 0.7855 & 0.6758 & 0.4001 & 0.4079 & $\begin{array}{l}0.6854 \\
-\end{array}$ & 0.5851 & 0.3094 & 0.8052 & 1 \\
\hline $\mathrm{Zr}$ & 0.0398 & 0.5781 & 0.2284 & 0.4926 & 0.4745 & 0.4349 & 0.4805 & 0.6987 & 0.1883 & 0.6573 & 0.5873 & 0.7588 & 0.3798 & 0.4576 & 0.5601 \\
\hline
\end{tabular}
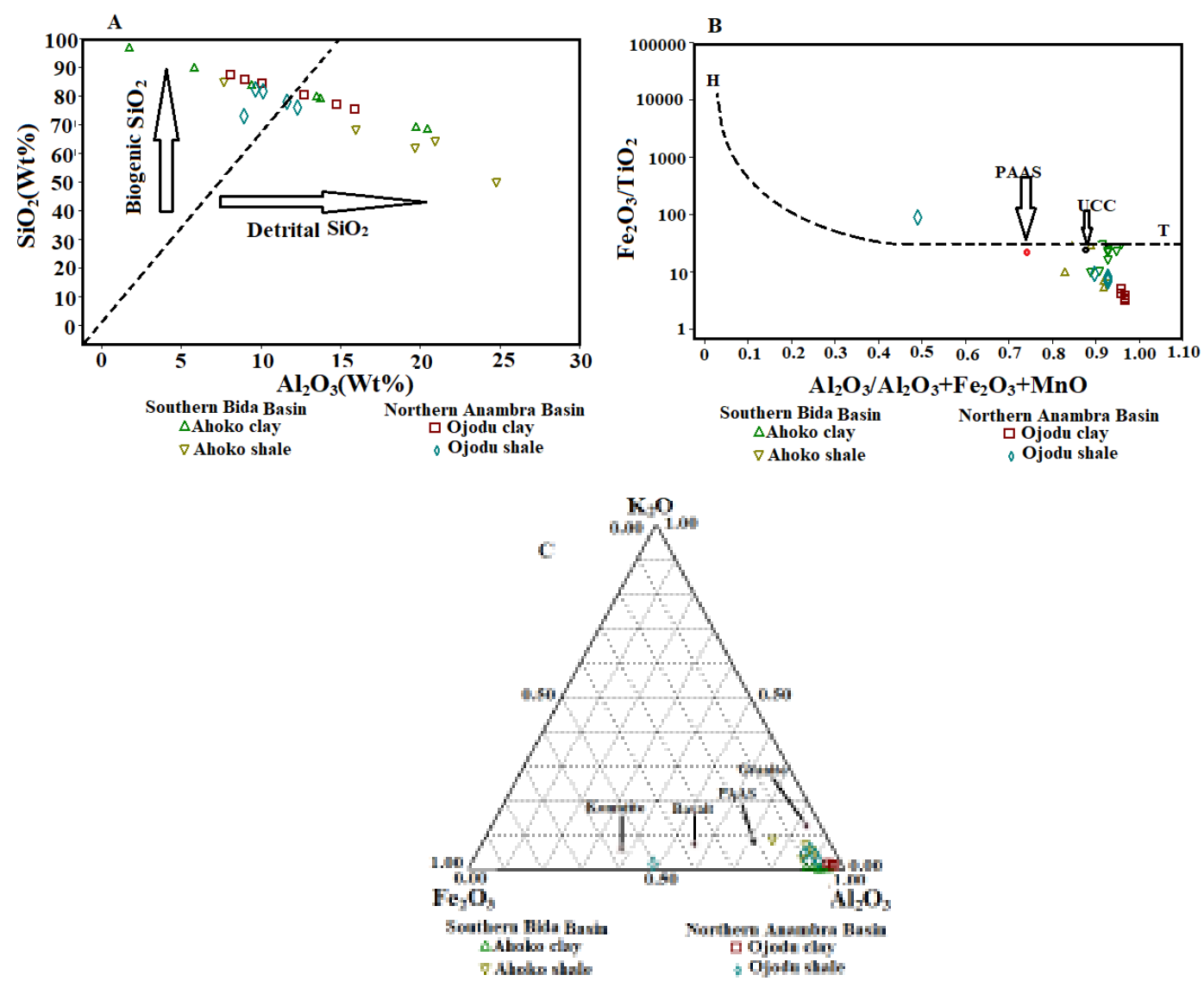

Fig. 4: (A). $\mathrm{Al}_{2} \mathrm{O}_{3}$ vs. $\mathrm{SiO}_{2}$ diagram showing the presence of biogenic contribution in the

investigated clay-shale sediments (Barbera et al., 2006), (B). Bostrom (1973) diagram; analysed sediments are compared to argillite (T) and hydrothermal $(\mathrm{H})$ end members whose mixing is modelled by the H-T curve. PAAS (Taylor McLennan, 1985) and UCC (Rudnick and Gao, 2003) data are reported for comparison, and (C). $\mathrm{K}_{2} \mathrm{O}-\mathrm{Fe}_{2} \mathrm{O}_{3}--\mathrm{Al}_{2} \mathrm{O}_{3}$ compositional space (Date after Condie, 1993) showing the major element distribution in the clay-shale sediments for both Southern Bida and Northern Anambra basins respectively. 
The detrital features and continental crust precursor of the analysed clay-shales are further supported by the high values $(0.49-0.97$; Tables 1 and 2$)$ of the parameter $D^{*}=\mathrm{Al}_{2} \mathrm{O}_{3} /\left(\mathrm{Al}_{2} \mathrm{O}_{3}+\mathrm{MnO}+\mathrm{Fe}_{2} \mathrm{O}_{3} ;\right.$ Machhour et al., 1994), which connects $\mathrm{Al}_{2} \mathrm{O}_{3}$, strongly assembled in the continental crust $\left(D^{*}=0.79\right.$; Taylor and McLennan, 1985). The ternary plot of $\mathrm{K}_{2} \mathrm{O}-\mathrm{Fe}_{2} \mathrm{O}_{3}-\mathrm{Al}_{2} \mathrm{O}_{3}$ (Fig. $4 \mathrm{C}$ ) reveals that all of the investigated clay and shales plots close to $\mathrm{Al}_{2} \mathrm{O}_{3}$ region, suggesting enrichment in $\mathrm{Al}_{2} \mathrm{O}_{3}$, which also indicates that clay minerals in these clayshale sediments largely controlled the abundance of elements (Wronkiewicz and Condie, 1987).

$\mathrm{MgO}$ content ranges between 0.01 to $0.14 \%$ (Table 1) for clay-shale sediments from Southern Bida Basin and 0.02 to $0.11 \%$ (Table 2) for sediments from Northern Anambra Basin, its lower than UCC value (2.22 \%). The correlation between $\mathrm{MgO}$ and $\mathrm{Fe}_{2} \mathrm{O}_{3}$ is strong and positive ( $r=0.59$ and 0.80 respectively; Table 5$)$ for the Southern Bida Basin sediments but for the Northern Anambra Basin Sediments, it was low and insignificant $(r=0.18$ and 0.13 , respectively; Table 6$)$. This oxides are sourced from ferromagnesian silicates, such as, biotites and amphiboles, which though may be minor constituents of felsic igneous or metamorphic rocks within the basins (Mishra et al. 2019).

The composition of $\mathrm{TiO}_{2}$ varied from 0.06 to 2.98 for the Southern Bida Basin sediments and $0.71 \%$ to $1.48 \%$ for the Northern Anambra Basin sediments (Tables 1 and 2). The high variation in value of $\mathrm{TiO}_{2}$ in some of the investigated samples is an indication of the detrital nature of the sediments in the presence of titanium minerals such as rutile and ilmenite, transported and deposited mechanically (Liu et al., 2009).

The positive correlation between $\mathrm{Al}_{2} \mathrm{O}_{3}$ and $\mathrm{TiO}_{2}(r=$ 0.49) for the Southern Bida Basin and Northern Anambra Basin $(r=0.87)$ suggest terrigenous origin (Saccà et al., 2011).

There is an observed general depletion in oxides of $\mathrm{Na}$, $\mathrm{K}$ and $\mathrm{Ca}$ in the investigated samples (Tables 1 and 2) compared to the Upper Continental Crust values, (3.9 $\%, 3.4 \%$ and $4.2 \%)$. This could be due to their hydration energy resulting in high mobility during weathering process (Cullers, 1995). The observed positive correlation between $\mathrm{Al}_{2} \mathrm{O}_{3}$ and both of $\mathrm{K}_{2} \mathrm{O}$ and $\mathrm{Na}_{2} \mathrm{O}(r=0.48$ and 0.74 ; Table 5) for the Southern Bida Basin and Northern Anambra Basin ( $r=0.13$ and 0.86; Table 6) confirms that these oxides are associated and related with clay minerals like smectite and illite. Above assertion was supported with the strong positive correlation recorded between $\mathrm{Na}_{2} \mathrm{O}$ and $\mathrm{K}_{2} \mathrm{O}(\mathrm{r}=0.74)$ for the Southern Bida and $(r=0.86)$ for the Northern Anambra Basins respectively.

Cox et al., (1995) put forward values of $\mathrm{K}_{2} \mathrm{O} / \mathrm{Al}_{2} \mathrm{O}_{3}$ ratios for clay minerals and feldspars at 0.0 to 0.3 and 0.3 to 0.9. The range of $\mathrm{K}_{2} \mathrm{O} / \mathrm{Al}_{2} \mathrm{O}_{3}$ ratio for the investigated claystone varied from 0.01 to 0.09 and 0.04 to 0.10 for the claystone and shales from the Southern Bida basin
(Table 1) while 0.01 to 0.02 and 0.03 to 0.07 for claystone and shale of the Northern Anambra Basin (Table 2). The $\mathrm{K}_{2} \mathrm{O} / \mathrm{Al}_{2} \mathrm{O}_{3}$ ratios were close to the lower clay mineral range limit in both the shale and clay samples from both basins.

Tables 7 and 8 give the concentration of the trace elements in the investigated Cretaceous samples from the Southern Bida and Northern Anambra Basins. It was generally observed that the sediments rich in quartz grain are characterized by lower composition of trace elements except $\mathrm{Zr}$, which is attributed to dilution by quartz.

Transitional metals like $\mathrm{Cr}$, $\mathrm{Co}, \mathrm{Ni}$ and $\mathrm{V}$ in the studied samples (Tables 7 and 8 ) show relatively high values of concentration compared to the corresponding values for $\operatorname{UCC}(35,10,20$, and $60 \mathrm{ppm}$, respectively). This suggests the presence of mafic components in the source area resulting in an increase of $\mathrm{Ni}, \mathrm{Co}, \mathrm{Cr}$ and $\mathrm{V}$ in the detritus (Liu et al., 2013). This is supported with the enrichment of the clayey constituents as $\mathrm{Cr}, \mathrm{Co}, \mathrm{Ni}$ and $\mathrm{V}$ elements are readily adsorbed onto clay minerals during weathering process. There was an observed strong positive correlation, $(r=0.69 ; 0.85 ; 0.62$ and 0.62 ) of $\mathrm{Al}_{2} \mathrm{O}_{3}$ concentration with $\mathrm{V}, \mathrm{Cr}, \mathrm{Ni}$ and $\mathrm{Co}$ for sediments of the Southern Bida Basin respectively (Table 5). This strongly suggests their presence as adsorbed ions in clay minerals and strongly controlled by the nature of the source rocks (EL-Wekeil and Abou El-Anwar, 2013). On the other hand, within the Northern Anambra Basin, there was a strong positive correlation of $\mathrm{Al}_{2} \mathrm{O}_{3}$ with $\mathrm{V}$ and $\mathrm{Cr}(\mathrm{r}=0.72$ and 0.91$)$ but insignificantly correlated with $\mathrm{Ni}$ and $\mathrm{Co}(r=r=0.13$ and -0.24) (Table 6). This must be as a result of renewed tectonic activity within the Northern Anambra Basin during the mid Santonia when the Lower Benue trough was displaced from its major depositional axis westward, thereby disturbing the sedimentation dynamics, possibly resulting in sediment mixing and reworking and finally forming the Anambra Basin (Obaje, 2009). The strong positive correlations between $\mathrm{Co}$ and $\mathrm{Ni}$ with $\mathrm{Fe}_{2} \mathrm{O}_{3}(r=$ 0.77 and $r=0.77$; Table 5) for the sediments from Southern Bida Basin and ( $r=0.99$ and $r=0.88$; Table 6) for the Northern Anambra Basin sediments strongly suggest possible association of these two elements with Fe-oxides minerals.

$\mathrm{Sr}$ and $\mathrm{Ba}$ show a general depletion pattern (Tables 7 and 8) compared to UCC (350 ppm and 550 ppm, Fig. $5)$, this is probably due to their hydration energy resulting in their preferential loss during weathering and erosion (Cullers, 1995 and Liua et al., 2013). The observed positive correlation between contents of $\mathrm{Fe}_{2} \mathrm{O}_{3}$ and $\mathrm{Ba}$ for the Southern Bida Basin $(r=0.799)$ and the Northern Anambra Basin $(r=0.074)$ indicates that $B a$ is mainly associated with Fe-oxides (EL-Wekeil and Abou El-Anwar, 2013). This is in good agreement with reports documented by Adeleye and Dessauvagie (1972) that Southern Bida Basin is a host to deposits of ironstone. 


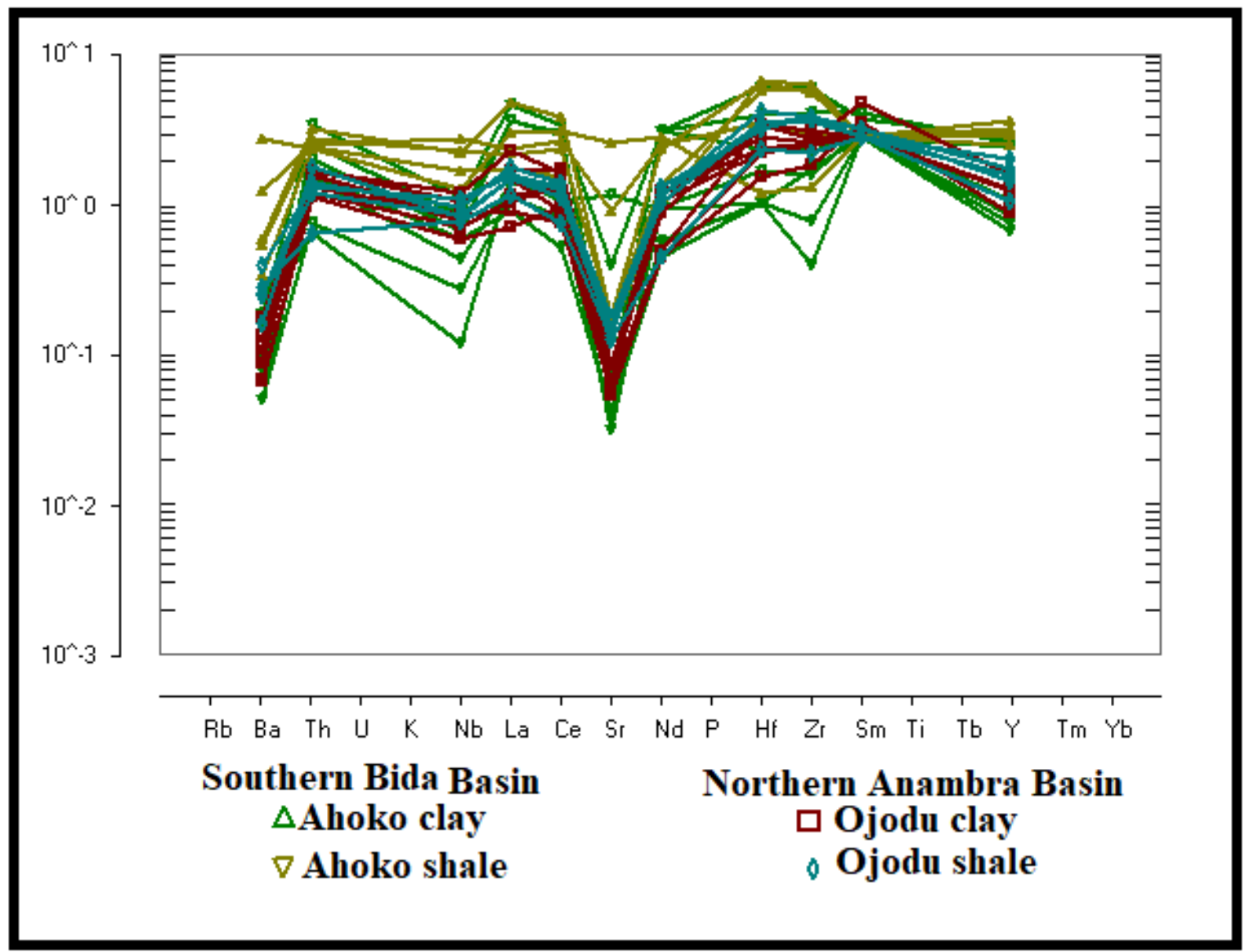

Fig. 5: UCC normalized for trace and rare earth elements of sediments from A: Southern Bida and B: Northern Anambra Basins (UCC After Taylor and Mclennan, 1981).

The observed negative correlation between $\mathrm{Sr}$ and $\mathrm{Ba}$ with $\mathrm{Zr}$ ( $r=-0.11$ and- 0.35; Table 5) for Southern Bida Basin suggest an abundance of fine-grained sediments whereas in the Northern Anambra Basin, the strong positive correlation values between $\mathrm{Sr}$ and $\mathrm{Ba}$ with $\mathrm{Zr}(\mathrm{r}$ $=0.76$ and 0.58; Table 6) suggest an abundance of coarse grained detrital sands. This confirms that the Northern Anambra Basin is more sandy than the Southern Bida Basin, evident from the high silica composition.

The compositional value of Th (Tables 7 and 8 ) is close to the corresponding value in the UCC (10.7 ppm, Fig. 5). Samples with higher Th contents suggest high sand enrichment. This is supported by the positive correlation between $\mathrm{Th}$ and $\mathrm{Zr}(\mathrm{r}=0.84$; Table 5) for the Southern Bida Basin and $(r=0.34$; Table 6$)$ for the Northern Anambra Basin. The positive correlation values of $\mathrm{Fe}$, $\mathrm{Ti}, \mathrm{Mg}, \mathrm{V}, \mathrm{Ni}$, Co and $\mathrm{Cr}(\mathrm{r}=0.91,0.79,0.75,0.93,0.76$ and 0.76; Table 5) for Southern Bida Basin and the positive correlation values $\mathrm{Ti}, \mathrm{Mg}, \mathrm{V}, \mathrm{Ni}$ and $\mathrm{Cr}(\mathrm{r}=0.92$, $0.52,0.87$, and 0.32 respectively, Table 6$)$ for the Northern Anambra Basin indicate that these elements may be incooperated with heavy minerals and/or trace elements during depositional episode or sedimentation within the Southern Bida and Northern Anambra Basins.

Table 7: Major element concentration of the Southern Bida claystone and shale samples

\begin{tabular}{|c|c|c|c|c|c|c|c|c|c|c|c|c|}
\hline & Abj1.1 & Abj1.2 & Abj1.3 & Abj1.4 & Abj1.5 & Abj1.6 & Abj1.7 & Ahk1.1 & Ahk1.2 & Ahk1.3 & Ahk1.4 & Ahk1.5 \\
\hline $\mathrm{Ba}$ & 36.00 & 56.00 & 119 & 134 & 36 & 36 & 70 & 872 & 1947 & 384 & 419 & 242 \\
\hline $\mathrm{Sr}$ & 11.00 & 26.00 & 417 & 142 & 15 & 14.00 & 23 & 324 & 914 & 64 & 65 & 50 \\
\hline $\mathrm{Ni}$ & 2.00 & 3.00 & 2.00 & 2.00 & 2.00 & 2.00 & 2.00 & 32.00 & 46 & 17 & 13 & 5 \\
\hline Co & 2.00 & 3.00 & 2.00 & 3.00 & 2.00 & 2.00 & 3.00 & 26 & 32 & 20 & 6 & 3 \\
\hline $\mathrm{Cu}$ & 8.00 & 10.00 & 10.00 & 10.00 & 10.00 & 9.00 & 10 & 28 & 26 & 18 & 26 & 9 \\
\hline $\mathrm{Cr}$ & 24.00 & 78.00 & 4.00 & 53.00 & 22.00 & 19.00 & 85 & 109 & 120 & 87 & 88 & 53 \\
\hline $\mathrm{Ga}$ & 18.00 & 25.00 & 6.00 & 15.00 & 11.00 & 15.00 & 25 & 30 & 41 & 27 & 36 & 19 \\
\hline Hf & 10.00 & 24.00 & 6.00 & 36.00 & 6.00 & 6.00 & 14 & 21 & 7 & 34 & 39 & 40 \\
\hline $\mathrm{Sc}$ & 8.00 & 15.00 & 8.00 & 10.00 & 8.00 & 8.00 & 10 & 18 & 17 & 14 & 27 & 9 \\
\hline $\mathrm{Zn}$ & 3.00 & 5.00 & 2.00 & 9.00 & 6.00 & 2.00 & 6.00 & 108 & 140 & 90 & 30 & 16 \\
\hline $\mathrm{V}$ & 20.00 & 51.00 & 5.00 & 37.00 & 25.00 & 17.00 & 53.00 & 109 & 96 & 96 & 71 & 58 \\
\hline $\mathrm{Zr}$ & 385 & 1005 & 96.00 & 1475 & 423 & 192 & 569 & 697 & 321 & 1438 & 1367 & 1554 \\
\hline Mo & 2.00 & 2.00 & 2.00 & 2.00 & 2.00 & 2.00 & 2.00 & 2.00 & 2.00 & 2.00 & 3 & 3 \\
\hline $\mathrm{Nb}$ & 11.00 & 22.00 & 3.00 & 29.00 & 15.00 & 7.00 & 17.00 & 70 & 33 & 59 & 57 & 43 \\
\hline $\mathrm{Pb}$ & 12.00 & 11.00 & 10.00 & 27.00 & 11.00 & 10.00 & 28 & 62 & 47 & 43 & 51 & 31 \\
\hline $\mathrm{Th}$ & 16.00 & 27.00 & 7.00 & 37.00 & 17.00 & 8.00 & 22.00 & 27.00 & 25 & 30 & 35 & 26 \\
\hline $\mathrm{U}$ & 3.00 & 8.00 & 3.00 & 8.00 & 3.00 & 3.00 & 4.00 & 14 & 8 & 11 & 11 & 8 \\
\hline
\end{tabular}


Table 8: Major element concentration of the Northern Anambra claystone and shale samples

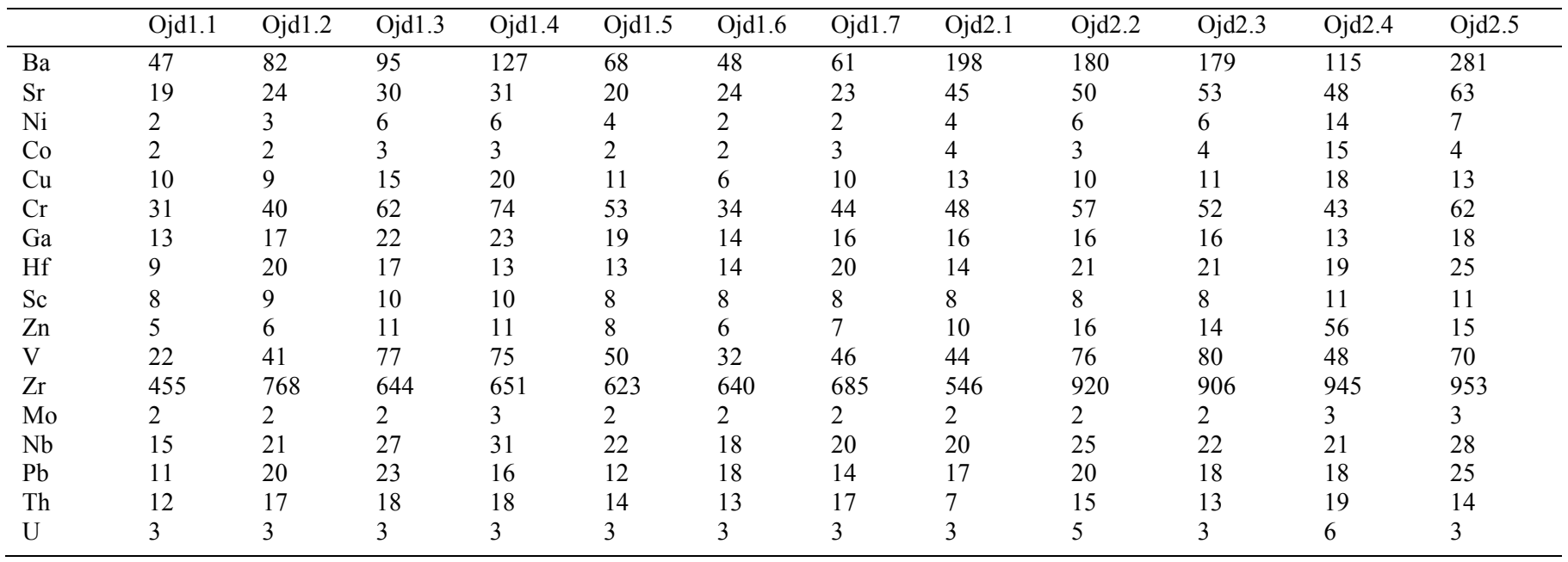

"Ojd1.1-Ojd1.7= Claystone samples

On the other hand, the observed negative correlation values recorded for $\mathrm{Fe}, \mathrm{Co}$ and $\mathrm{Cr}(r=-0.10$ and -0.06 respectively, Table 6) for some samples in the Northern Anambra Basin suggest probable disturbance of the sedimentation dynamics, resulting in sediment mixing, reworking and size sorting (Moosavirada et al., 2010).

\subsection{Paleo-Weathering Indices and Maturity of the}

\section{Clay-Shale deposit}

The average values of Chemical index of alteration (CIA), Plagioclase Index of Alteration (PIA) and Chemical Index of Weathering (CIW) for the clay samples in the Southern Bida basin are 99.11\%,
*Ojd2.1-Ojd2.5= Shale samples

Table 9: Summary of source area weathering for Southern Bida and Northern Anambra claystone and shale deposits

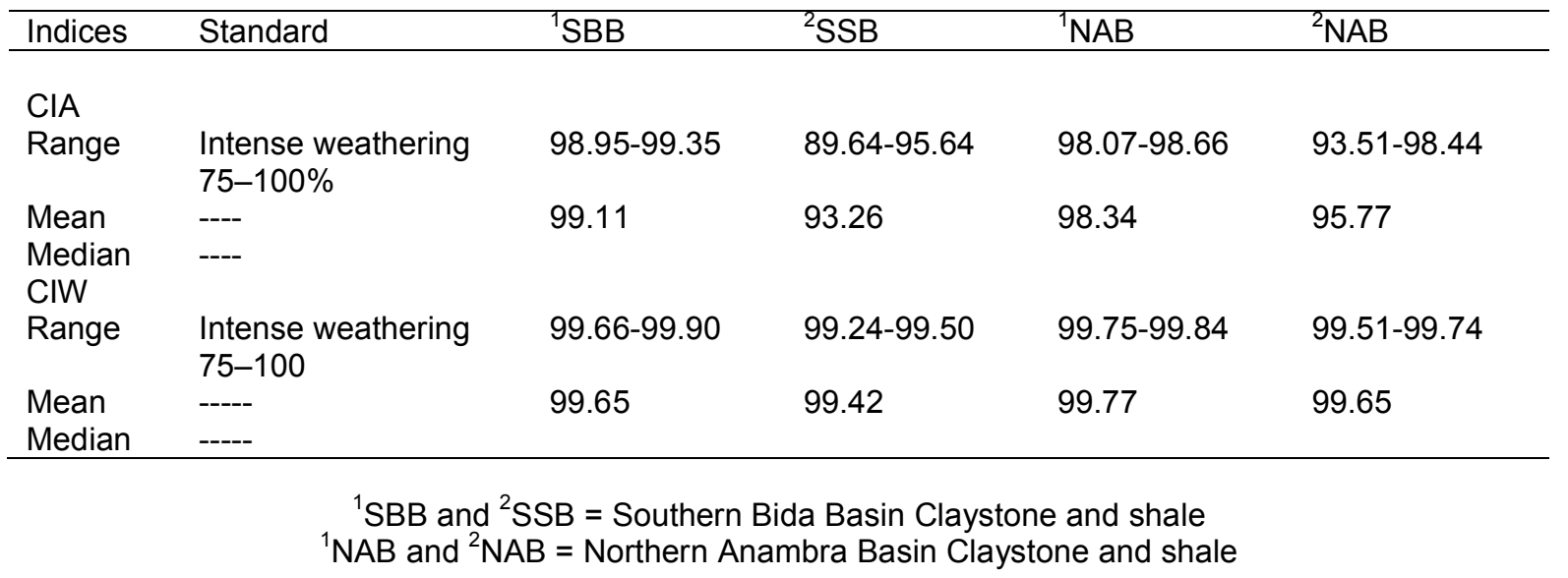

The $\mathrm{Al}_{2} \mathrm{O}_{3}-\left(\mathrm{CaO}+\mathrm{Na}_{2} \mathrm{O}\right)-\mathrm{K}_{2} \mathrm{O}(\mathrm{A}-\mathrm{CN}-\mathrm{K})$ diagram (Fig. $6 \mathrm{~A})$ of Nesbith and Young (1982) and Fedo et al. (1995) permit the segregation in compositional variations as related to chemical weathering and/or source rock composition (Madhavaraju et al., 2016), it demonstrated intense weathering history. The clay-shale sediments sourced from both Southern Bida and Northern Anambra Basins plot close to the high $\mathrm{Al}_{2} \mathrm{O}_{3}$ contents (A-Apex), thus revealing a high level of weathering to a point where there is liberation of major amounts of alkali and alkali earth elements from the
$99.65 \%$, 99.65\%, respectively whereas the shale samples have average values of $93.26 \%, 99.45 \%$, $99.42 \%$, respectively for these indices. On the other hand, CIA, PIA and CIW indices for clay samples from the Northern Anambra averaged 98.34\%, 98.07\%, $99.77 \%$ whereas shale averaged $95.77 \%, 91.05 \%$, $99.65 \%$, respectively. The high PIA indicates that nearly all of the plagioclase has been transformed into clay minerals. This is consistent with the calculated $\mathrm{CIA}$ and CIW indices that reveal strong or prolonged weathering in the source area (Nesbitt and Young, 1982; Fedo et al., 1995; Tables 1, 2 and 9). 
(ICV) can be used to categorize the original nature and

conditions

(Cox

et

al.,

1995).
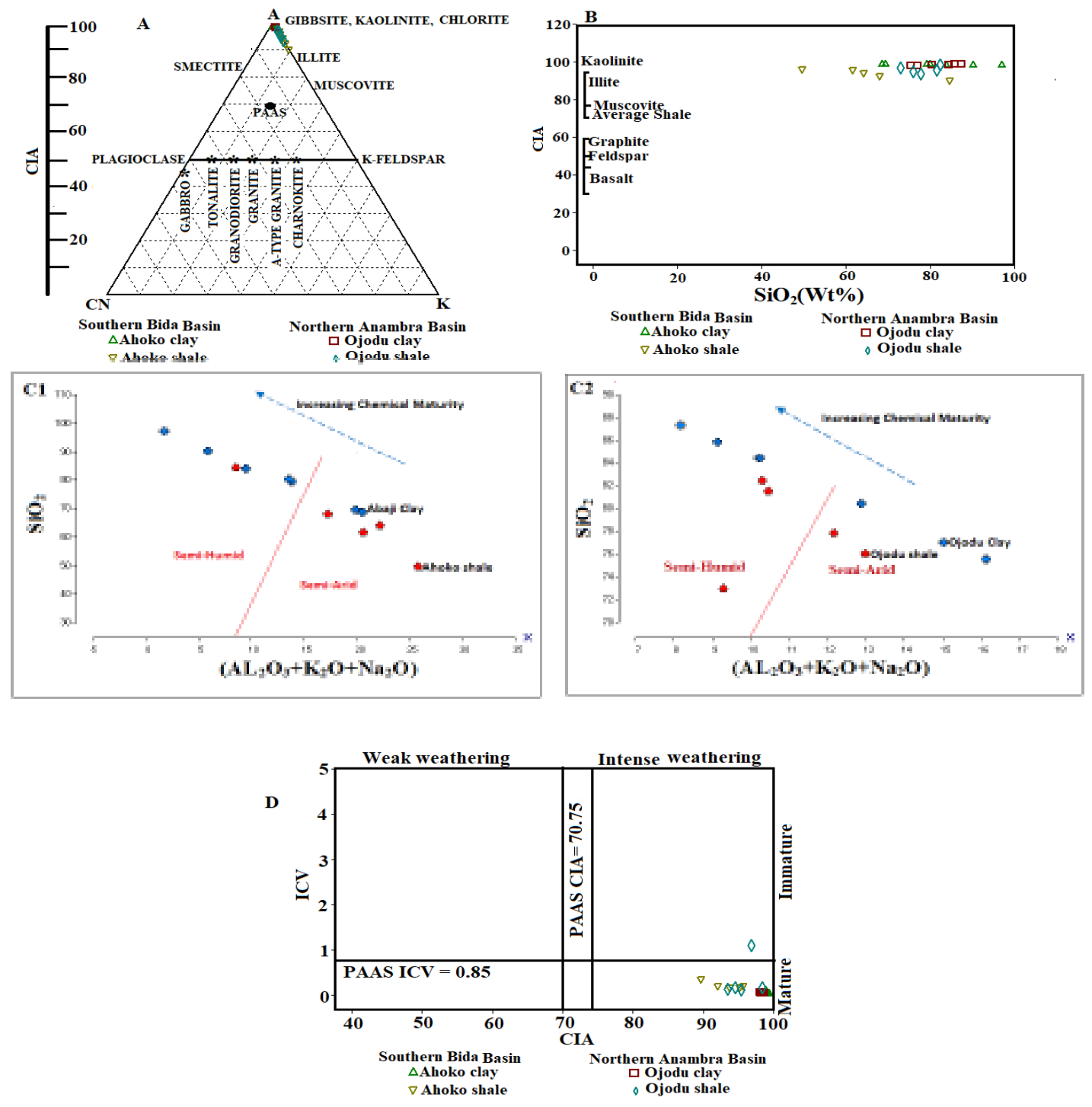

Fig. 6: (A). Ternary plot of $\mathrm{Al}_{2} \mathrm{O}_{3}-\left(\mathrm{CaO}+\mathrm{Na}_{2} \mathrm{O}\right)-\mathrm{K}_{2} \mathrm{O}$ for the sediments (Nesbith and Young,

1982; Fedo et al., 1995), (B). Plot of ClA vs. SiO2 (Nesbitt and Young 1982), $\mathrm{SiO}_{2} \mathrm{Vs}\left(\mathrm{AL}_{2} \mathrm{O}_{3}+\mathrm{K}_{2} \mathrm{O}+\mathrm{Na}_{2} \mathrm{O}\right)$ for claystone-shale sediments of C1: Southern Bida and C2: Northern Anambra Basin showing trend of maturity with reference to climatic conditions (Suttner and Dutta, 1986) (D). ICV vs. ClA plot showing the maturity and intensity of chemical weathering for the Shales (After Long et al., 2012).

$\mathrm{ICV}=\left(\mathrm{Fe}_{2} \mathrm{O}_{3}+\mathrm{K}_{2} \mathrm{O}+\mathrm{Na}_{2} \mathrm{O}+\mathrm{CaO}+\mathrm{MgO}+\mathrm{MnO}\right) / \mathrm{Al}_{2} \mathrm{O}_{3}$ Values of ICV $<1$ are characteristic of minerals such as kaolinite, illite and muscovite whereas higher values points toward plagioclase, K-feldspar, amphiboles and pyroxenes Also, the more mature the sediment, the low the ICV values. Tables 1 and 2 illustrate that the documented ICV values for the investigated Southern Bida basin and Northern Anambra basin sediments ranged from 0.06 to 0.33 and 0.05 to 1.10 , respectively. Hence, these sediments are considered to be highly matured and are derivative of intense chemical weathering. This may also imply distinctive clay rich mature sediments associated with either tectonically inactive or intracratonic setting, where sediment recycling is dynamic (Cox et al., 1995) or from intensely weathered crystalline basements, which is consistent with Fig. 6D established by Long et al. (2012) for the estimation of sediment maturity and weathering intensity. This also conforms well to the results obtained from the association between $\mathrm{SiO}_{2}$ and $\left(\mathrm{Al}_{2} \mathrm{O}_{3}+\mathrm{Na}_{2} \mathrm{O}+\right.$ $\mathrm{K}_{2} \mathrm{O}$ ) shown in Fig. 6C1 and 6C2.

Relationship between $\mathrm{Th} / \mathrm{U}$ ratio and $\mathrm{Th}$ concentration can be used to estimate the degree of weathering in sedimentary rocks. The observed result indicates intense weathering in the source areas or sedimentary recycling for the clay in both basins but the shale indicative of moderate to high weathering (Tables 10 and 11). 
Table 10: Calculated geochemical ratios for the investigated samples of Southern Bida Basin

\begin{tabular}{|c|c|c|c|c|c|c|c|c|c|c|c|c|}
\hline & Abj1.1 & Abj1.2 & Abj1.3 & Abj1.4 & Abj1.5 & Abj1.6 & Abj1.7 & Ahk1.1 & Ahk1.2 & Ahk1.3 & Ahk1.4 & Ahk1.5 \\
\hline $\mathrm{Th} / \mathrm{Co}$ & 8.00 & 9.00 & 3.5 & 12.33 & 8.5 & 4.00 & 7.33 & 1.04 & 0.78 & 1.5 & 5.83 & 12 \\
\hline $\mathrm{Co} / \mathrm{Th}$ & 0.13 & 0.11 & 0.29 & 0.08 & 0.12 & 0.25 & 0.14 & 0.96 & 1.28 & 0.67 & 0.17 & 0.12 \\
\hline $\mathrm{Co} / \mathrm{La}$ & 0.05 & 0.03 & 0.04 & 0.02 & 0.07 & 0.06 & 0.03 & 0.36 & 0.34 & 0.30 & 0.04 & 0.06 \\
\hline $\mathrm{Th} / \mathrm{U}$ & 5.33 & 3.40 & 2.33 & 4.63 & 5.67 & 2.67 & 5.50 & 1.93 & 3.13 & 2.73 & 3.18 & 3.25 \\
\hline $\mathrm{La} / \mathrm{Sc}$ & 5.38 & 7.33 & 6.13 & 14.3 & 3.5 & 4.38 & 11.1 & 4.06 & 5.47 & 4.79 & 5.44 & 5.89 \\
\hline $\mathrm{La} / \mathrm{Co}$ & 21.5 & 63.67 & 24.5 & 47.67 & 14 & 17.5 & 37 & 2.81 & 2.91 & 3.35 & 24.5 & 17.67 \\
\hline $\mathrm{Th} / \mathrm{Cr}$ & 0.67 & 0.35 & 1.75 & 0.70 & 0.77 & 0.42 & 0.23 & 0.25 & 0.21 & 0.34 & 0.40 & 0.15 \\
\hline $\mathrm{Th} / \mathrm{Sc}$ & 2.00 & 1.80 & 1.75 & 3.7 & 2.13 & 1.00 & 2.20 & 1.50 & 1.47 & 2.14 & 1.30 & 2.89 \\
\hline $\mathrm{Cu} / \mathrm{Zn}$ & 2.67 & 2.00 & 5.00 & 1.11 & 1.67 & 4.50 & 1.67 & 0.26 & 0.19 & 0.20 & 0.87 & 0.56 \\
\hline $\mathrm{Ni} / \mathrm{Co}$ & 1.00 & 1.00 & 1.00 & 0.67 & 1.00 & 1.00 & 0.67 & 1.23 & 1.44 & 0.85 & 2.17 & 1.67 \\
\hline $\mathrm{Zr} / \mathrm{Sc}$ & 48.13 & 67 & 12.00 & 147.5 & 54 & 24 & 56.9 & 38.72 & 18.88 & 102.71 & 50.63 & 172.67 \\
\hline $\mathrm{Cr} / \mathrm{Th}$ & 1.5 & 2.89 & 0.57 & 1.43 & 1.29 & 2.38 & 3.86 & 4.04 & 4.80 & 2.90 & 2.51 & 2.04 \\
\hline $\mathrm{Cr} / \mathrm{La}$ & 0.56 & 0.71 & 0.08 & 0.37 & 0.79 & 0.54 & 0.77 & 1.49 & 1.29 & 1.30 & 0.60 & 1.00 \\
\hline $\mathrm{U} / \mathrm{Th}$ & 0.19 & 0.30 & 0.43 & 0.22 & 0.18 & 0.34 & 0.18 & 0.52 & 0.32 & 0.37 & 0.31 & 0.31 \\
\hline $\mathrm{V} / \mathrm{Cr}$ & 0.83 & 0.65 & 1.25 & 0.70 & 1.14 & 0.89 & 0.62 & 1.00 & 0.80 & 1.10 & 0.81 & 1.09 \\
\hline $\mathrm{Ni} / \mathrm{Co}$ & 1.00 & 1.00 & 1.00 & 0.67 & 1.00 & 1.00 & 0.67 & 1.23 & 1.44 & 0.85 & 2.17 & 1.67 \\
\hline $\mathrm{Cr} / \mathrm{Ni}$ & 12.00 & 26.00 & 2.00 & 26.5 & 11.00 & 18.50 & 42.50 & 3.41 & 2.61 & 5.12 & 6.77 & 10.60 \\
\hline $\mathrm{V} / \mathrm{Ni}$ & 10.00 & 17.00 & 2.50 & 18.50 & 12.50 & 8.50 & 26.50 & 3.41 & 2.09 & 5.65 & 5.46 & 11.60 \\
\hline $\mathrm{Cu} / \mathrm{Zn}$ & 2.67 & 2.00 & 5.00 & 1.11 & 1.67 & 4.50 & 1.67 & 0.26 & 0.19 & 0.20 & 0.96 & 0.56 \\
\hline $\mathrm{Cu}+\mathrm{Mo} / \mathrm{Zn}$ & 3.33 & 2.4 & 6.00 & 1.33 & 6.00 & 5.50 & 6.00 & 0.28 & 0.20 & 0.22 & 0.97 & 0.69 \\
\hline $\mathrm{Sr} / \mathrm{Ba}$ & 0.31 & 0.46 & 3.50 & 1.06 & 0.42 & 0.39 & 0.33 & 0.37 & 0.47 & 0.17 & 0.16 & 0.21 \\
\hline $\mathrm{D}^{*}$ & 0.93 & 0.93 & 0.89 & 0.91 & 0.96 & 0.93 & 0.92 & 0.89 & 0.92 & 0.93 & 0.83 & 0.95 \\
\hline
\end{tabular}

\section{$D^{*}=\mathrm{Al}_{2} \mathrm{O}_{3} /\left(\mathrm{Al}_{2} \mathrm{O}_{3}+\mathrm{MnO}+\mathrm{Fe}_{2} \mathrm{O}_{3} ;\right.$ Machhour et al., 1994) \\ *Abj1.1- Abj1.7= Claystone samples \\ *Ahk1.1-Ahk1.5= Shale samples}

\subsection{Paleo-Environmental Conditions and \\ Provenance of the Clay-Shale deposit}

$\mathrm{Sr} / \mathrm{Ba}$ ratio have proven to be a very important tool employed by previous studies to estimate paleo-salinity (Chen et al., 2016). Sr/Ba ratios $>1,0.5-1$, and $<0.5$ propose seawater, brackish water, and freshwater conditions, correspondingly ( Li et al., 2018). The Sr/Ba ratios (0.16-3.50; Table 10) for the investigated clay- shales from the Southern Bida basin reveal an array of depositional paleo-environment that alternated between marine and continental settings. On the other hand, the recorded Sr/Ba ratios $(0.22-0.50$; Table 11$)$ revealed a continental setting for the Northern Anambra basin. In addition, $\mathrm{K}_{2} \mathrm{O} / \mathrm{Al}_{2} \mathrm{O}_{3}$ and $\mathrm{MgO} / \mathrm{Al}_{2} \mathrm{O}_{3}$ diagram of Roaldset (1978) was used to differentiate between marine and non-marine sediments.

Table 11: Calculated geochemical ratios for the investigated samples of Northern Anambra Basin

\begin{tabular}{|c|c|c|c|c|c|c|c|c|c|c|c|c|}
\hline & Ojd1.1 & Ojd1.2 & Ojd1.3 & Ojd1.4 & Ojd1.5 & Ojd1.6 & Ojd1.7 & Ojd2.1 & Ojd2.2 & Ojd2.3 & Ojd2.4 & Ojd2.5 \\
\hline $\mathrm{Th} / \mathrm{U}$ & 4 & 5.67 & 6 & 6 & 4.67 & 4.33 & 5.67 & 2.33 & 3 & 4.33 & 3.17 & 4.67 \\
\hline $\mathrm{Th} / \mathrm{Co}$ & 6 & 8.5 & 6 & 6 & 7 & 6.5 & 5.67 & 1.75 & 5 & 3.25 & 1.27 & 3.5 \\
\hline $\mathrm{La} / \mathrm{Sc}$ & 2.75 & 5 & 5.1 & 7.1 & 3.5 & 4 & 4.5 & 4.5 & 6.88 & 6 & 4.12 & 4.36 \\
\hline $\mathrm{La} / \mathrm{Co}$ & 11.00 & 22.50 & 17.00 & 23.67 & 14.00 & 16.00 & 12.00 & 9.00 & 18.33 & 11.50 & 3.07 & 12.00 \\
\hline $\mathrm{Co} / \mathrm{Th}$ & 0.17 & 0.12 & 0.17 & 0.17 & 0.14 & 0.15 & 0.18 & 0.57 & 0.20 & 0.31 & 0.79 & 0.29 \\
\hline $\mathrm{Co} / \mathrm{La}$ & 0.09 & 0.04 & 0.06 & 0.04 & 0.07 & 0.06 & 0.08 & 0.11 & 0.05 & 0.09 & 0.33 & 0.08 \\
\hline $\mathrm{Th} / \mathrm{Cr}$ & 0.39 & 0.43 & 0.29 & 0.24 & 0.26 & 0.38 & 0.39 & 0.15 & 0.26 & 0.25 & 1.46 & 0.23 \\
\hline $\mathrm{Th} / \mathrm{Sc}$ & 1.50 & 1.89 & 1.80 & 1.80 & 1.75 & 1.63 & 2.13 & 0.88 & 1.88 & 1.63 & 1.73 & 1.27 \\
\hline $\mathrm{Cu} / \mathrm{Zn}$ & 1.25 & 1.50 & 1.36 & 1.82 & 1.38 & 1.00 & 1.43 & 1.30 & 0.63 & 0.79 & 0.32 & 0.89 \\
\hline $\mathrm{Ni} / \mathrm{Co}$ & 1.00 & 1.50 & 2.00 & 2.00 & 2.00 & 1.00 & 0.67 & 1.00 & 2.00 & 1.50 & 0.93 & 1.75 \\
\hline $\mathrm{Zr} / \mathrm{Sc}$ & 56.88 & 85.33 & 64.40 & 65.10 & 77.88 & 80.00 & 85.63 & 68.25 & 115 & 113.25 & 85.91 & 86.64 \\
\hline $\mathrm{Cr} / \mathrm{Th}$ & 2.58 & 2.35 & 3.44 & 4.11 & 3.79 & 2.62 & 2.59 & 6.86 & 3.80 & 4.00 & 2.26 & 4.43 \\
\hline $\mathrm{Cr} / \mathrm{La}$ & 1.41 & 0.89 & 1.22 & 1.04 & 1.89 & 1.06 & 1.22 & 1.33 & 1.04 & 1.13 & 0.93 & 1.29 \\
\hline U/Th & 0.25 & 0.18 & 0.17 & 0.17 & 0.21 & 0.23 & 0.18 & 0.43 & 0.33 & 0.23 & 0.32 & 0.21 \\
\hline $\mathrm{V} / \mathrm{Cr}$ & 0.71 & 1.03 & 1.24 & 1.01 & 0.94 & 0.94 & 1.05 & 0.92 & 1.33 & 1.54 & 1.12 & 1.13 \\
\hline $\mathrm{Ni} / \mathrm{Co}$ & 1.00 & 1.50 & 2.00 & 2.00 & 2.00 & 1.00 & 0.67 & 1.00 & 2.00 & 1.50 & 0.93 & 1.75 \\
\hline $\mathrm{Cr} / \mathrm{Ni}$ & 15.50 & 13.33 & 10.33 & 12.33 & 13.25 & 17.00 & 22.00 & 12.00 & 9.50 & 8.67 & 3.07 & 8.86 \\
\hline $\mathrm{V} / \mathrm{Ni}$ & 11.00 & 13.67 & 12.83 & 12.50 & 12.50 & 16.00 & 23.00 & 11.00 & 12.67 & 13.33 & 3.43 & 10.00 \\
\hline $\mathrm{Cu} / \mathrm{Zn}$ & 2.00 & 1.50 & 1.36 & 1.82 & 1.38 & 1.00 & 1.43 & 1.30 & 0.63 & 0.79 & 0.32 & 0.19 \\
\hline $\mathrm{Cu}+\mathrm{Mo} / \mathrm{Zn}$ & 2.40 & 1.83 & 1.55 & 2.09 & 1.63 & 1.33 & 1.71 & 1.50 & 0.75 & 0.93 & 0.38 & 0.23 \\
\hline $\mathrm{Sr} / \mathrm{Ba}$ & 0.40 & 0.29 & 0.32 & 0.24 & 0.29 & 0.50 & 0.38 & 0.23 & 0.28 & 0.30 & 0.42 & 0.22 \\
\hline $\mathrm{D}^{*}$ & 0.97 & 0.97 & 0.96 & 0.97 & 0.96 & 0.97 & 0.97 & 0.93 & 0.93 & 0.93 & 0.49 & 0.90 \\
\hline
\end{tabular}

$D^{*}=\mathrm{Al}_{2} \mathrm{O}_{3} /\left(\mathrm{Al}_{2} \mathrm{O}_{3}+\mathrm{MnO}+\mathrm{Fe}_{2} \mathrm{O}_{3} ;\right.$ Machhour et al., 1994)

*Ojd2.1-Ojd2.5= Shale samples

The Southern Bida and Northern Anambra basin's clay shales sediments plot in the non-marine to slightly near marine environment (Fig. 7A), suggesting a transitional/mixed environment of deposition, consistent with bivariant plot of $\mathrm{V}$ vs. $\mathrm{Al}_{2} \mathrm{O}_{3}$ (Fig. 7B; Mortazavi et al., 2014). This is supported by the chemical classification on the basis of $\left(\mathrm{Al}_{2} \mathrm{O}_{3}\right)-\left(\mathrm{K}_{2} \mathrm{O}+\mathrm{Na}_{2} \mathrm{O}+\mathrm{CaO}\right)-$
$\left(\mathrm{Fe}_{2} \mathrm{O}_{3}+\mathrm{MgO}\right)$ contents $(\mathrm{AKF})$ proposed by Englung and Jorgensen (1973) were the clay - shale sediments under investigation plots in the continental zone and in an argillaceous area (Fig. 7C1-C2).

Trace element geochemical ratios like $\mathrm{Ni} / \mathrm{Co}$ and $\mathrm{V} / \mathrm{Cr}$ have proved to be reliable tools for redox determination in depositional environments (Jones and Manning, 1994; 
Nagarajan et al., 2007; Madhavaraju et al., 2016). Jones and Manning (1994) proposed that $\mathrm{V} / \mathrm{Cr}$ ratios $<2$ infer oxic conditions, $2-4.25$ dysoxic conditions, and $>4.25$ suboxic to anoxic conditions. They also found that $<5$ $\mathrm{Ni} / \mathrm{Co}$ ratios assumed oxic conditions, 5-7 means dysoxic conditions while $>7$ imply suboxic to anoxic conditions. The Ni/Co and $\mathrm{V} / \mathrm{Cr}$ of the investigated clay shale sediments (Tables 10 and 11; Fig. 7D) suggest oxic environments.

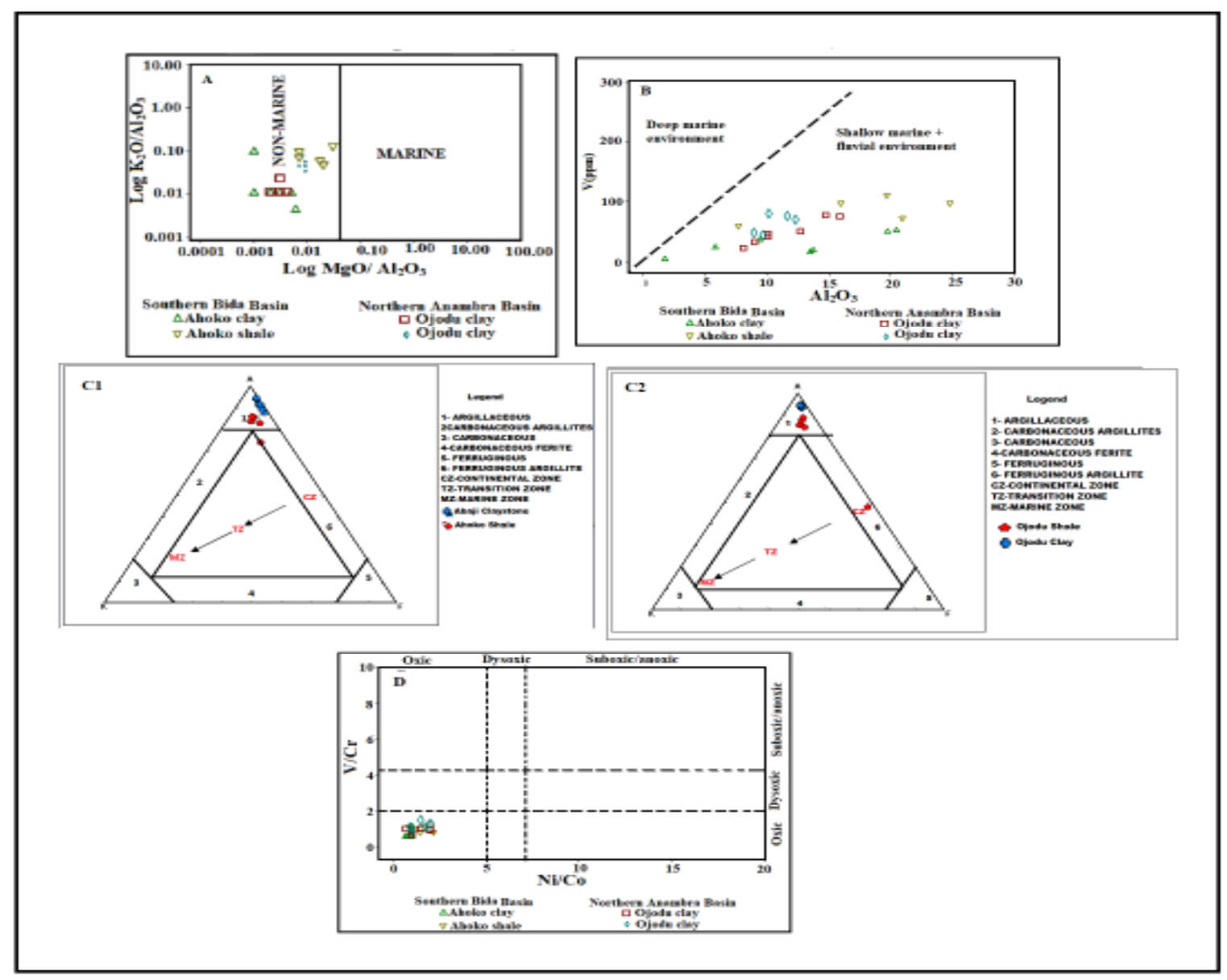

Fig. 7: Paleo-environmental reconstruction and redox-sensitivity of the investigated clay-shale

sediments from Southern Bida and Northern Anambra basins on A). Log $\mathrm{K}_{2} \mathrm{O} / \mathrm{Al}_{2} \mathrm{O}_{3}$ vs $\mathrm{Log} \mathrm{MgO} / \mathrm{Al}_{2} \mathrm{O}_{3}$ bivariate plot (After Roaldset, 1978), B). V vs. $\mathrm{Al}_{2} \mathrm{O}_{3}$ bivariate plot (After Mortazavi et al., 2014), C1-C2). $\mathrm{Al}_{2} \mathrm{O}_{3}-\left(\mathrm{K}_{2} \mathrm{O}+\mathrm{Na}_{2} \mathrm{O}+\mathrm{CaO}\right)-\left(\mathrm{Fe}_{2} \mathrm{O}_{3}+\mathrm{MgO}\right)$ [AKF] Ternary plots and D) Cross plot of $\mathrm{V} / \mathrm{Cr}$ vs. Ni/Co (After Jones and Manning 1994).

In addition to the paleo-environmental conditions, other trace elemental ratios like $\mathrm{U} / \mathrm{Th}$ and $\mathrm{Cu} / \mathrm{Zn}$ were also considered. According to Jones and Manning, (1994), ratios of U/Th $<0.75$ infers oxic conditions, while U/Th ratios > 1.25 indicate anoxic conditions. Moreso, Hallberg (1976) proposed that low ratios of $\mathrm{Cu} / \mathrm{Zn}$ in a basin reveals oxidizing depositional conditions, whereas high $\mathrm{Cu} / \mathrm{Zn}$ ratios suggests reducing depositional conditions. The primarily high ratios of U/Th (1.93-5.67; Table 9) and $\mathrm{Cu} / \mathrm{Zn}$ (0.19-5.00; Table 9) for the Southern Bida basin affirms a more reducing or an anoxic condition of deposition for the studied clay-shale sediments while the predominantly low ratios of U/Th (0.17 - 0.25; Table 10) and Cu/Zn (0.19 - 2.00; Table $10)$ for the Northern Anambra reveals an oxic condition of deposition for sediments studied.

Authors like Taylor and Mclennan, 1985; Condie et al, 1992; Cullers, 1995; Armstrong-Altrin et al., 2004; 2013; Madhavaraju et al., 2016; Chen et al., 2016 reports that geochemical signatures of clastic sediments can be used to ascertain provenance characteristics. $\mathrm{Al}_{2} \mathrm{O}_{3} / \mathrm{TiO}_{2}$ ratios for most clastic sediments can be used to infer source rock composition. According to Hayashi et al.,
1997, $\mathrm{Al}_{2} \mathrm{O}_{3} / \mathrm{TiO}_{2}$ ratios increase from 3 to 8 for mafic igneous rocks, 8 to 21 for intermediate rocks and 21 to 70 for felsic igneous rocks. The $\mathrm{Al}_{2} \mathrm{O}_{3} / \mathrm{TiO}_{2}$ ranged from 9.92 to 61.83 in the clays and 4.71 to 21.70 in the shale samples of the Southern Bida Basin; hence, this study's $\mathrm{Al}_{2} \mathrm{O}_{3} / \mathrm{TiO}_{2}$ ratio suggest intermediate and felsic rocks for the clay samples while mafic and intermediate rocks were suggested as being source rocks for the shale samples. For the clays and shale samples of the Northern Anambra Basin, $\mathrm{Al}_{2} \mathrm{O}_{3} / \mathrm{TiO}_{2}$ ratio ranged from 9.52 to 11.33 and 8.49 to 10.14 , respectively, suggesting intermediate rocks as being probable source rocks for the clay and shale (Tables 1 and 2). To also discriminate felsic, intermediate, and mafic provenance, bivariate plot of $\mathrm{Al}_{2} \mathrm{O}_{3} / \mathrm{TiO}_{2}$ vs. $\mathrm{SiO}_{2}$ (Le Bas et al., 1986) was employed. The investigated clay - shale sediments for both basins plot in both intermediate and felsic fields (Fig. 8A), indicating contributions from both sources. Trace elements such as $\mathrm{Y}, \mathrm{Th}, \mathrm{Nb}, \mathrm{Zr}, \mathrm{Hf}$, and $\mathrm{Sc}$ with REE in clastic sedimentary rocks are useful tool for their source rock interpreting. These elements have very low mobility during sedimentary processes, and are probably quantitatively transferred to the clastic sediments during 
the weathering, transportation, and diagenetic processes, thus reflecting the signatures of the precursors (e.g., Bhatia and Crook, 1986; McLennan, 1989; Armstrong Altrin et al., 2004). Different authors have also employed geochemical variations between elements such as La and Th (felsic source rocks) and Sc and $\mathrm{Cr}$ (mafic source rocks) to distinguish between felsic and mafic origin (Ramachandran et al. 2016). The plot of Th/Co vs. La/Sc (Fig. 8B) proved that the clay shale sediments for both basins were derivative of felsic origin. This was supported with $\mathrm{Hf}$ vs. La/Th diagram (Fig. 8C; Floyd and Leveridge, 1987), $\mathrm{TiO}_{2}$ (wt. \%) Vs. $\mathrm{Ni}$ (ppm) diagram (Fig. 7D; Floyd et al., 1989), V-NiTh*10 ternary relationship (Fig. 9A; Bracciali et al., 2007) and the Th/Sc vs. Zr/Sc relationship (Fig. 9B;
McLennan et al. 1993; Willan, 2003). The plot of Th/Sc vs. $\mathrm{Zr} / \mathrm{Sc}$ indicated an igneous differentiation trend, close to PAAS composition for the clay - shale sediments under investigation, therefore, no significant signs of heavy mineral concentration due to zircon enrichment. Thus, the recycling of older mature sediments of felsic and crustal origin probably did not play a significant role (Mikes, 2006). In addition, Co/Th vs. La/Sc diagram (Fig. 9C) demonstrated a main distribution between felsic and andesitic sources, while the La-Th-Sc relationship (Fig. 9D; Cullers, 1994a, b) revealed contributions from felsic sources, intermediate sources or possible mixing between felsic and basic source rocks.

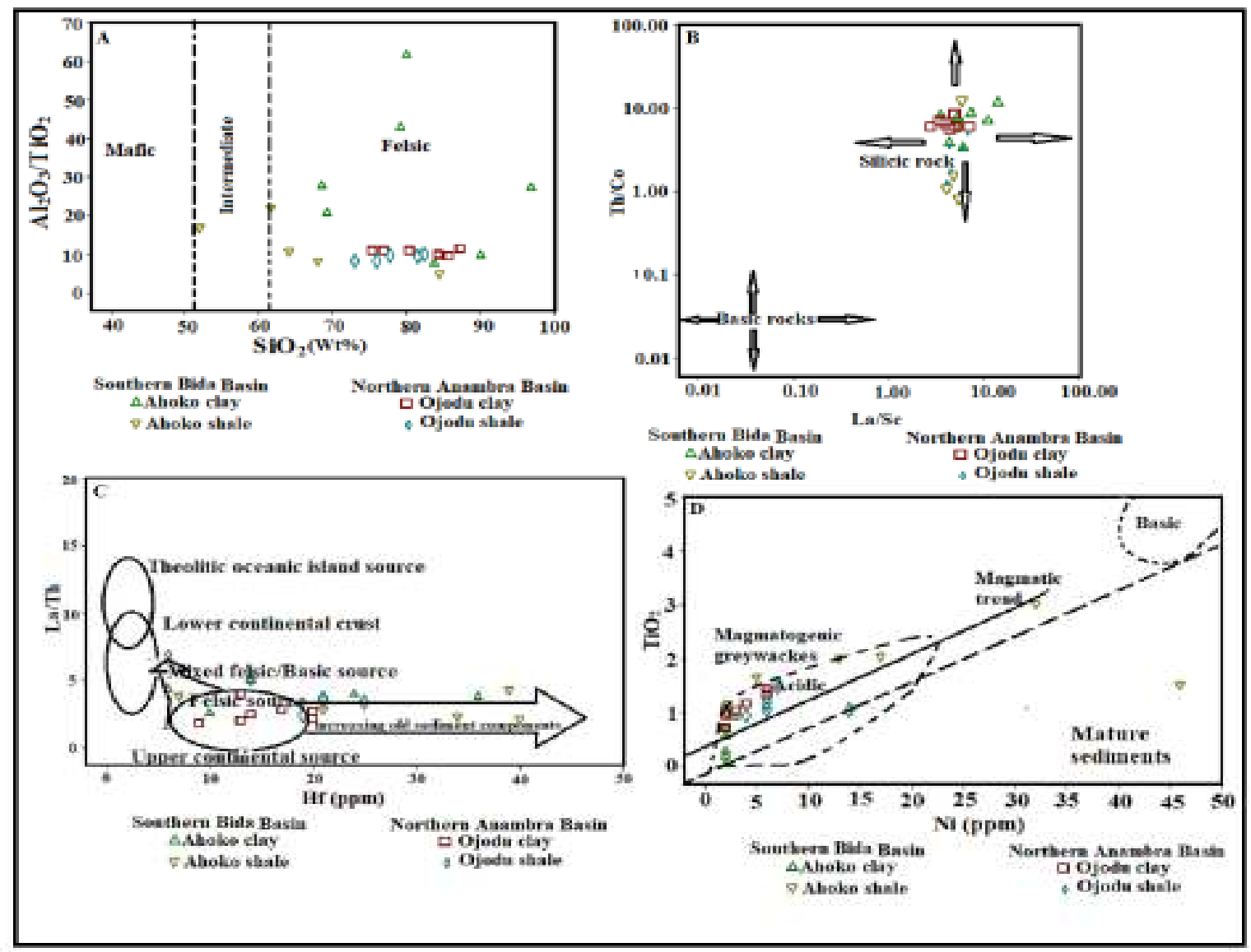

Fig. 8: A) Scatter diagram of $\mathrm{Al}_{2} \mathrm{O}_{3} / \mathrm{TiO}_{2}$ vs. $\mathrm{SiO}_{2}$ for the investigated clay and shale samples

(Le Bas et al., 1986; Zaid and Al Gahtani, 2015), B) Bivariate plot of La/Sc vs. Th/Co (after Cullers, 2002) C) La/Th ratio vs. Hf plot (Fields after Floyd and Leveridge, 1987 and Gu et al., 2002) D) TiO2 vs. Ni plot. Fields and trends after Floyd et al. (1989). 


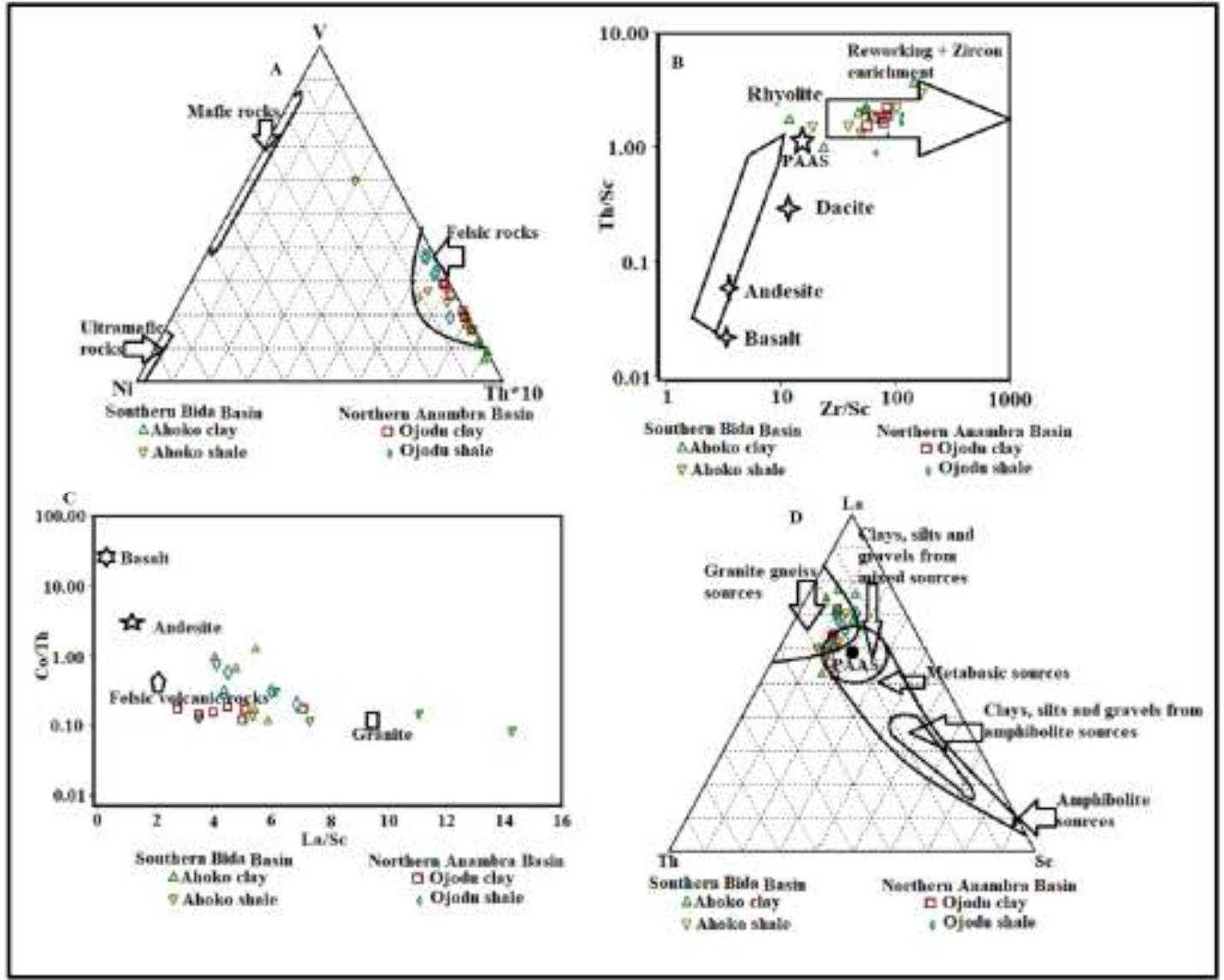

Fig. 9: (A) V-Ni-Th*10 plot of the shales (Bracciali et al., 2007), (B) Th/Sc vs. Zr/Sc plot

showing a magmatic arc trend (McLennan et al. 1993; Willan 2003), (C) Co/Th vs. La/Sc bivariate plot (McLennan et al., 1993) and (D) La-Th-Sc

Ternary plot for the shales after Cullers (1994a) compared with Post-Archean Average Shale (data is from Taylor and McLennan, 1985).

La/Sc, Th/Co and Th/Sc ratios are significantly different in felsic and basic rocks which can be used to infer provenance composition (Wronkiewicz and Condie, 1990; Cox et al., 1995; Cullers, 1995). The Th/Co, Th/Sc and $\mathrm{La} / \mathrm{Sc}$ ratios for shale and clay samples from this study were compared to those of felsic and basic rockderived sediment (fine fraction) upper continental crust (UCC) and PAAS values (Tables 10, 11 and 12). These comparisons also indicated that such ratios came within the range of felsic source rocks.

Table 12: Range of claystone and shale element ratios in this study compared to ratios for similar fractions derived from felsic rocks, mafic rocks, upper continental crust and post-archean Australia shale

\begin{tabular}{|c|c|c|c|c|c|c|c|c|}
\hline \multirow{2}{*}{$\begin{array}{l}\text { Elemental } \\
\text { ratio }\end{array}$} & \multicolumn{2}{|c|}{ Claystone $^{1}$} & \multicolumn{2}{|c|}{ Shale $^{1}$} & \multicolumn{2}{|c|}{ Range of sediments ${ }^{2}$} & \multirow{2}{*}{$\begin{array}{l}\text { Upper } \\
\text { Continental } \\
\text { Crust }^{3}\end{array}$} & \multirow{2}{*}{$\begin{array}{l}\text { Post- } \\
\text { archean } \\
\text { average } \\
\text { shale }^{3}\end{array}$} \\
\hline & SBB & NAB & SBB & NAB & $\begin{array}{l}\text { Felsic } \\
\text { rocks }\end{array}$ & $\begin{array}{l}\text { Mafic } \\
\text { rocks }\end{array}$ & & \\
\hline $\mathrm{Th} / \mathrm{Sc}$ & $1.00-3.70$ & $1.50-2.13$ & $1.30-3.70$ & $0.88-1.88$ & $\begin{array}{l}0.84- \\
20.50\end{array}$ & $\begin{array}{l}0.05- \\
0.22\end{array}$ & 0.79 & 0.90 \\
\hline Th/Co & $\begin{array}{l}3.50- \\
12.33\end{array}$ & $5.67-8.50$ & $\begin{array}{l}0.78- \\
12.00\end{array}$ & $1.27-5.00$ & $\begin{array}{l}0.67- \\
19.40\end{array}$ & $\begin{array}{l}0.04- \\
1.00\end{array}$ & 0.63 & 0.63 \\
\hline $\mathrm{La} / \mathrm{Sc}$ & $\begin{array}{l}3.50- \\
11.10\end{array}$ & $2.75-7.10$ & $4.06-5.89$ & $4.12-6.88$ & $\begin{array}{l}2.50- \\
16.30\end{array}$ & $\begin{array}{l}0.43- \\
0.86\end{array}$ & 2.21 & 2.40 \\
\hline
\end{tabular}


4.3. Tectonic Setting and Depositional Environment of the Clay-Shale deposit

In this research, major element-based discrimination diagrams of Roser and Korsch (1986) were employed. The binary diagram of $\log \left(\mathrm{K}_{2} \mathrm{O} / \mathrm{Na}_{2} \mathrm{O}\right)-\mathrm{SiO}_{2}$ discrimination diagram (Figs. 10A and 10B; Roser and Korsch, 1986) reveals that the clay - shale sediments for both basins plot entirely in the field of passive margin.
Passive-margin type sediments are generally enriched in $\mathrm{SiO}_{2}$ and depleted in $\mathrm{Na}_{2} \mathrm{O}, \mathrm{CaO}$ and $\mathrm{TiO}_{2}$, thereby revealing their highly recycled and matured nature (Bhatia, 1983). Major element analysis of the studied shale and clay samples confirm this, as all these samples were enriched in $\mathrm{SiO}_{2}$ but depleted in $\mathrm{Na}_{2} \mathrm{O}$, $\mathrm{CaO}$ and $\mathrm{TiO}_{2}$.

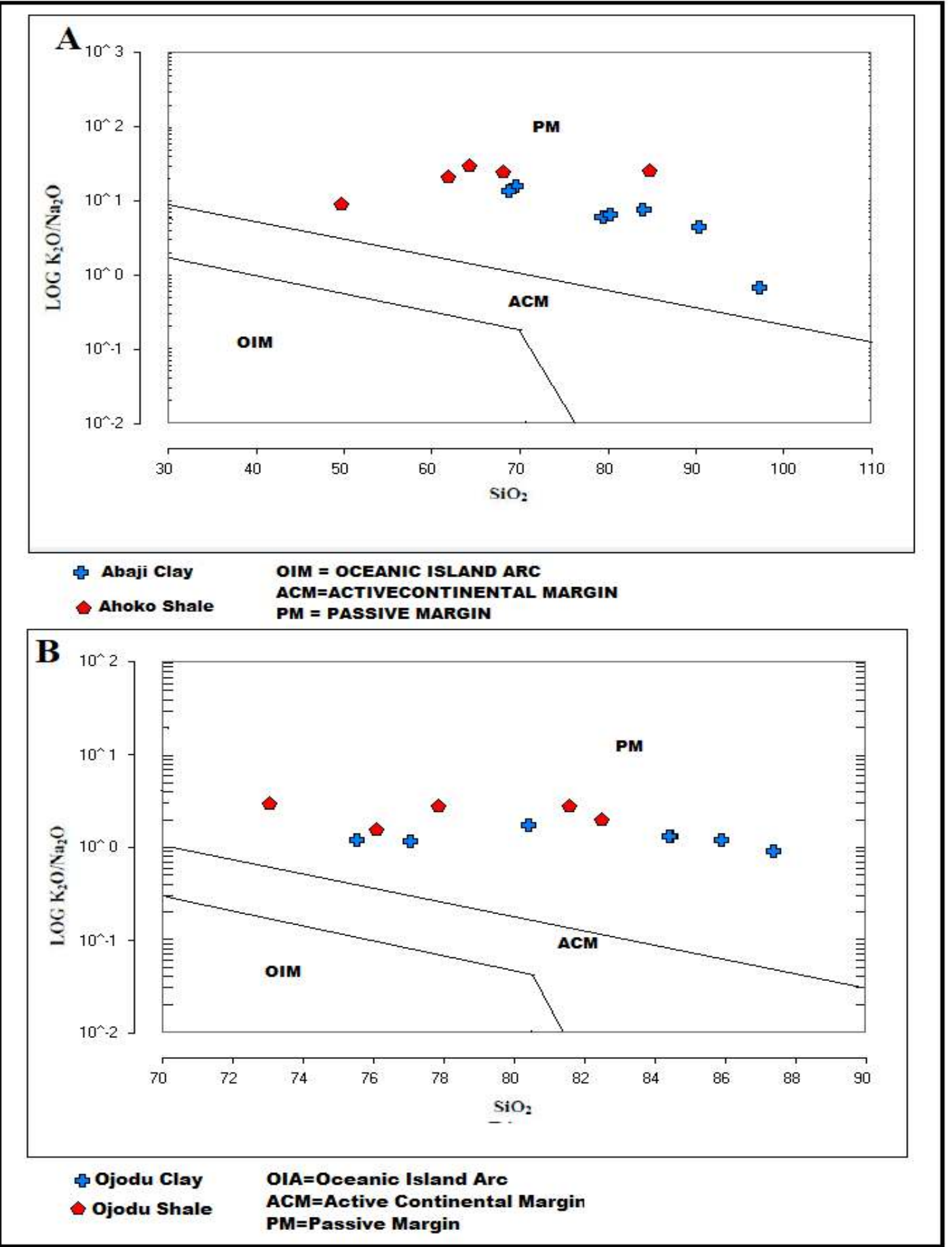

Fig. 10: Tectonic Discriminant Diagram for sediments of A: Southern Bida Basin and B: Northern Anambra Basin (Roser and Korsch, 1986). 

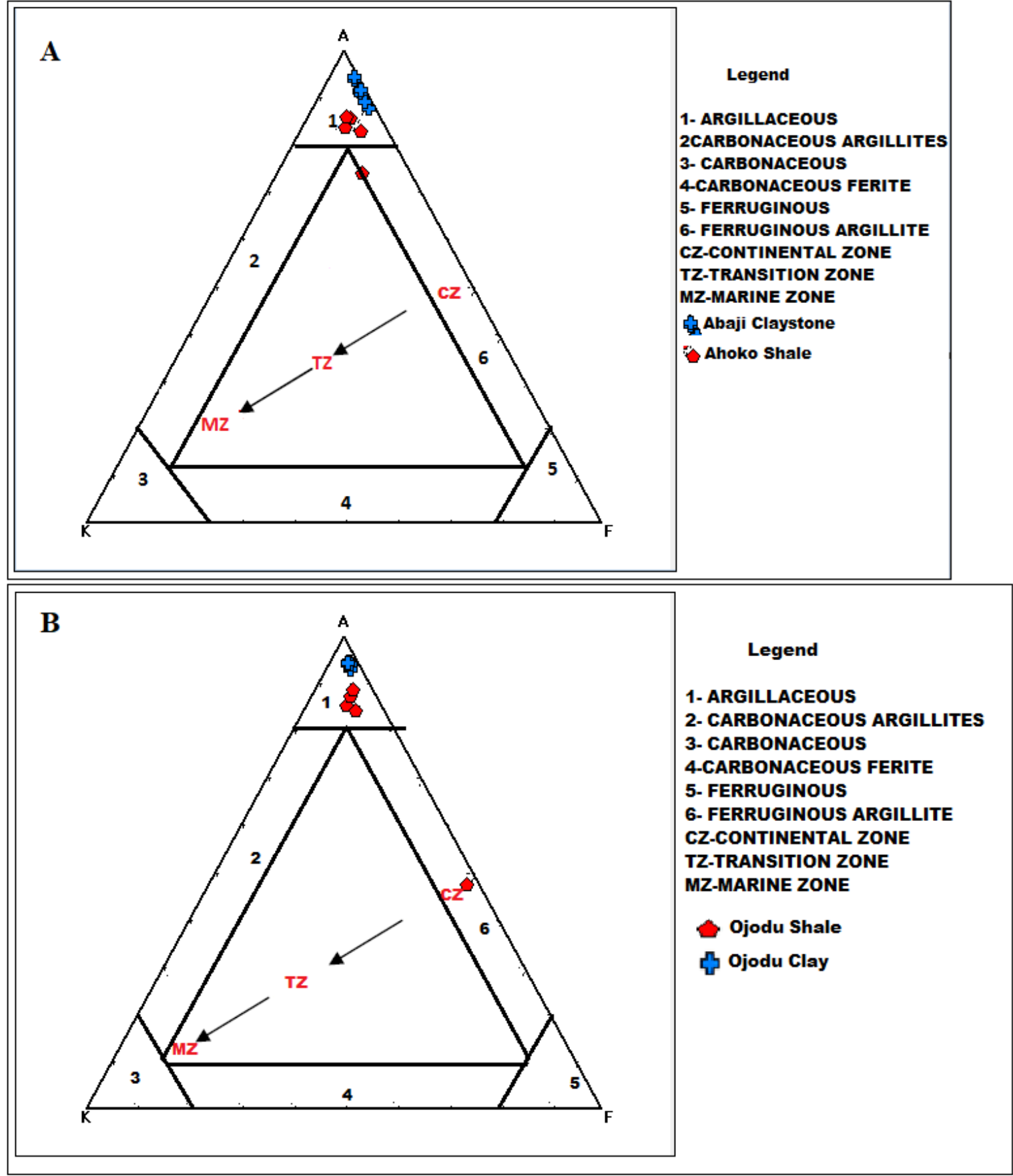

Fig. 11: $\mathrm{Al}_{2} \mathrm{O}_{3}-\left(\mathrm{K}_{2} \mathrm{O}+\mathrm{Na}_{2} \mathrm{O}+\mathrm{CaO}\right)-\left(\mathrm{Fe}_{2} \mathrm{O}_{3}+\mathrm{MgO}\right)[\mathrm{AKF}$; after Englund and Jorgensen, 1973).] Ternary plots for A: Southern Bida and B: Northern Anambra Basin

The compositional values for clay and shale samples' rare earth element (REE) are given in Tables 13 and 14 . A slight variation in sum of REE content was observed between the claystone and shale samples; (114-353) and (267-459) for Southern Bida, (138-255) and (142234) for the Northern Anambra Basins, respectively, these values were compared with notable world averages (Table 15). The enrichment of LREE and moderately negative Eu anomaly reflect their relative abundance in the crust, while the depletion of the HREE is due to their ability to form soluble complexes in seawater. 
Table 13: Rare earth element distribution of shales and claystone samples from Southern Bida Basin

\begin{tabular}{|c|c|c|c|c|c|c|c|c|c|c|c|c|}
\hline & Abj1.1 & Abj1.2 & Abj1.3 & Abj1.4 & Abj1.5 & Abj1.6 & Abj1.7 & Ahk1.1 & Ahk1.2 & Ahk1.3 & Ahk1.4 & Ahk1.5 \\
\hline \multicolumn{13}{|c|}{ Light Rare Earth Elements (LREE) } \\
\hline La & 43 & 110 & 49 & 143 & 28 & 35 & 111 & 73 & 93 & 67 & 147 & 53 \\
\hline Sm & 15 & 19 & 13 & 17 & 13 & 13 & 13 & 13 & 13 & 13 & 13 & 13 \\
\hline \multicolumn{13}{|c|}{ Heavy Rare Earth Elements (HREE) } \\
\hline Sc & 8 & 15 & 8 & 10 & 8 & 8 & 10 & 18 & 17 & 14 & 27 & 9 \\
\hline \multicolumn{13}{|c|}{ LREE/HREE Ratios } \\
\hline $\mathrm{Ce} / \mathrm{Sc}$ & 9.75 & 12.73 & 8.75 & 22.10 & 4.25 & 6.75 & 19.60 & 9.67 & 12.06 & 11.00 & 9.33 & 11.22 \\
\hline $\mathrm{Ce} / \mathrm{Y}$ & 1.79 & 3.24 & 4.67 & 3.54 & 1.79 & 3.18 & 3.56 & 2.38 & 3.66 & 1.88 & 3.60 & 1.55 \\
\hline $\mathrm{La} / \mathrm{Y}$ & 1.79 & 1.84 & 3.27 & 2.31 & 1.47 & 2.06 & 2.02 & 1.00 & 1.66 & 0.82 & 2.10 & 0.82 \\
\hline
\end{tabular}

Table 14: Rare earth element distribution of shales and claystone samples from Northern Anambra Basin

\begin{tabular}{|c|c|c|c|c|c|c|c|c|c|c|c|c|}
\hline & Ojd1.1 & Ojd1.2 & Ojd1.3 & Ojd1.4 & Ojd1.5 & Ojd1.6 & Ojd1.7 & Ojd2.1 & Ojd2.2 & Ojd2.3 & Ojd2.4 & Ojd2.5 \\
\hline \multicolumn{13}{|c|}{ Light Rare Earth Elements (LREE) } \\
\hline $\mathrm{Ce}$ & 64 & 59 & 114 & 107 & 49 & 86 & 83 & 49 & 90 & 84 & 74 & 85 \\
\hline La & 22 & 45 & 51 & 71 & 28 & 32 & 36 & 36 & 55 & 46 & 46 & 48 \\
\hline $\mathrm{Nd}$ & 12 & 23 & 31 & 28 & 12 & 33 & 13 & 12 & 27 & 31 & 35 & 31 \\
\hline Sm & 16 & 13 & 13 & 22 & 13 & 13 & 13 & 13 & 15 & 13 & 15 & 13 \\
\hline \multicolumn{13}{|c|}{ Heavy Rare Earth Elements (HREE) } \\
\hline Sc & 8 & 9 & 10 & 10 & 8 & 8 & 8 & 8 & 8 & 8 & 11 & 11 \\
\hline Y & 20 & 29 & 36 & 36 & 28 & 24 & 28 & 24 & 32 & 36 & 39 & 46 \\
\hline ¿REE & 142 & 178 & 255 & 267 & 138 & 196 & 181 & 142 & 227 & 218 & 220 & 234 \\
\hline \multicolumn{13}{|c|}{ LREE/HREE Ratios } \\
\hline $\mathrm{Ce} / \mathrm{Sc}$ & 8.00 & 6.56 & 11.40 & 10.70 & 6.13 & 10.75 & 10.38 & 6.13 & 11.25 & 10.50 & 6.72 & 7.72 \\
\hline $\mathrm{Ce} / \mathrm{Y}$ & 3.20 & 2.03 & 3.17 & 2.97 & 1.75 & 3.58 & 2.96 & 2.04 & 2.81 & 2.33 & 1.90 & 1.85 \\
\hline $\mathrm{La} / \mathrm{Y}$ & 1.10 & 2.03 & 1.42 & 1.97 & 1.00 & 1.33 & 1.29 & 1.50 & 1.72 & 1.28 & 1.18 & 1.04 \\
\hline
\end{tabular}

Table 15: Average rare earth elements of claystone and shales from Southern Bida and Northern Anambra Basins

\begin{tabular}{llllllll}
\hline Element & \multicolumn{2}{c}{ Claystone $^{1}$} & \multicolumn{3}{c}{ Shale $^{1}$} & PAAS & $\begin{array}{l}\text { Codo shale } \\
\text { (McLennan et al., } \\
1980)\end{array}$ \\
& SBB & NAB & SBB & NAB & & $\begin{array}{l}\text { Average shale } \\
\text { (Levinson, 1974) }\end{array}$ \\
& & & & & & & \\
\hline $\mathrm{La}$ & 74.14 & 80.29 & 86.60 & 76.40 & 38.20 & 29.70 & 121.00 \\
$\mathrm{Ce}$ & 120.57 & 40.71 & 177.20 & 46.20 & 79.60 & 63.40 & 50.00 \\
$\mathrm{Pr}$ & - & - & - & - & 8.83 & - & - \\
$\mathrm{Nd}$ & 46.71 & 21.74 & 53.00 & 27.20 & 33.90 & 27.90 & 24.00 \\
$\mathrm{Sm}$ & 14.71 & 14.71 & 13.00 & 13.80 & 5.55 & - & - \\
$\mathrm{Eu}$ & - & - & - & - & 1.08 & - & - \\
$\mathrm{Gd}$ & - & - & - & - & 4.66 & - & - \\
$\mathrm{Tb}$ & - & - & - & - & 0.74 & - & - \\
$\mathrm{Dy}$ & - & - & - & - & 4.68 & - & - \\
$\mathrm{Ho}$ & - & - & - & - & 0.99 & - & - \\
$\mathrm{Er}$ & - & - & - & - & 2.85 & - & - \\
$\mathrm{Tm}$ & - & - & - & - & 0.41 & - & - \\
$\mathrm{Lu}$ & - & - & - & - & 0.43 & - & - \\
$\mathrm{Y}$ & 35.86 & 28.71 & 69.20 & 35.40 & - & - & - \\
$\mathrm{Sc}$ & 9.57 & 8.74 & 17.00 & 9.20 & - & - & \\
\hline
\end{tabular}




\section{CONCLUSION}

The major and trace element analyses of sediments from Northern Anambra and Southern Bida Basins were carried out. The result shows that $\mathrm{SiO}_{2}$ range from 49.69 - $97.02 \mathrm{wt} \%$ for Southern Bida Basin and 72.99 87.31 wt $\% \mathrm{SiO}_{2}$ with moderate $\mathrm{Al}_{2} \mathrm{O}_{3}$, low $\mathrm{Fe}_{2} \mathrm{O}_{3}$ and $\mathrm{K}_{2} \mathrm{O}$ values for Northern Anambra Basin, which are consistent with a quartz-rich clayey mineral assemblage. The clay-shale sediments for both basins were derived from intense chemical weathering as shown by the high CIA (>90), PIA (>90) and CIW (>90) values. This is supported with the ICV values of $0.06-0.33$ for Southern Bida Basin and $0.05-1.10$ for the Northern Anambra basin that indicates a highly matured and characteristic intensive chemically weathered products. $\mathrm{Th} / \mathrm{Sc}, \mathrm{La} / \mathrm{Sc}, \mathrm{Th} / \mathrm{Co}, \mathrm{TiO}_{2}$ vs $\mathrm{Al}_{2} \mathrm{O}_{3}$ and REEs data indicate a dominantly felsic (granodioritic) provenance whereas the $\mathrm{Cu} / \mathrm{Zn}, \mathrm{Cu}+\mathrm{Mo} / \mathrm{Zn}$ and $\mathrm{U} / \mathrm{Th}$ evaluations reveal an oxic depositional environment for the clay shale deposits. The log of $\left(\mathrm{K}_{2} \mathrm{O} / \mathrm{Na}_{2} \mathrm{O}\right)$ vs $\mathrm{SiO}_{2}$ show Passive Margin tectonic setting, in addition, $\mathrm{Al}_{2} \mathrm{O}_{3}$ $\left(\mathrm{K}_{2} \mathrm{O}+\mathrm{Na}_{2} \mathrm{O}+\mathrm{CaO}\right)-\left(\mathrm{Fe}_{2} \mathrm{O}_{3}+\mathrm{MgO}\right)$ [AKF] diagram indicated continental depositional environment for both basins, respectively. In summary, this study show existence of insignificant differences between the geochemical classifications, weathering, source rock/provenance and tectonic settings of clay-shale sediments of both sedimentary basins, however, there exist slight disparity in their salinity conditions and redox environment.

\section{REFERENCES}

Akande, S. O., Ojo, O. J. and Ladipo, K. O., 2005. Upper Cretaceous Sequences in the Southern Bida Basin, Nigeria: A Field Guidebook. NAPE Geological Field Guide, No. 1. Ibadan, Mosuro Publishers. p. 60.

Adeleye, D. R., Dessauvagie, T. F. J., 1972. Stratigraphy of the Niger embayment near Bida, Nigeria in Africa Geology. (T. F. J. Dessauvagie and A. J. Whiteman, Eds). University of Ibadan Press, page $181-186$.

Adeleye, D. R., 1974. Sedimentology of the fluvial Bida Sandstone (Cretaceous), Nigeria. Sedimentary Geology, 12: 1-24.

Agyingi, C. M., 1991. Geology of Upper Cretaceous rocks in the eastern Bida, Nigeria. Unpublished Ph.D. Thesis. Department of Geology, University of Ibadan, 501pp.

Akpokodje, E. G., Etu-Efeotor, J. O and Olorunfemi, B. N., 1991 The composition and physical properties of some ceramic and pottery clays of South Eastern Nigeria. Journal of Mining and Geology, 27, 9-15.

Armstrong-Altrin, J. S., Lee, Y. I., Verma, S. P., Ramasamy, S., 2004. Geochemistry of sandstones from the upper Miocene Kudankulam Formation, southern India: Implications for provenance, weathering, and tectonic setting. Journal of Sedimentary Research, 74, 285- 297.

Armstrong-Altrin, J. S., 2009. Provenance of sands from Cazones, Acapulco, and Bahıa Kino beaches, Mexıco. Rev. Mex. Cienc. Geol. 26 (3) 764-782.

Armstrong-Altrin, J. S. Nagarajan, R., Madhavaraju, J., Rosalez-Hoz, L., Lee, Y., Balaram, V.,

Cruz-Martınez, A., Avila-Ramırez, G., 2013. Geochemistry of the Jurassic and Upper Cretaceous shales from the Molango Region, Hidalgo, eastern Mexico: Implications for source-area weathering, provenance, and tectonic setting. C. R. Geoscience, 345, 185 202.

Bakkiaraj, D., Nagendra, R., Nagarajan, R. and Armstrong-Altrin, J. S., 2010. Geochemistry of sandstones from the Upper Cretaceous Sillakkudi Formation, Cauvery Basin, southern India: implication for provenance. J. Geol. Soc. India 76, 453-467.

Barbera, G., Mazzoleni, P., Critelli, S., Pappalardo, A., Lo Giudice, A., Cirrincione, R., 2006. Provenance of shales and sedimentary history of the Monte Soro Unit, Sicily. Periodico di Mineralogia, 75(2-3), 313-330.

Bhatia, M. R. and Taylor, S. R., 1981. Trace-element geochemistry and sedimentary provinces: a study from the Tasman geosyncline, Australia. Chemical Geology, 33, 115- 125.

Bhatia, M. R. and Crook, K. A. W., 1986. Trace Element Characteristics of Graywackes and Tectonic Setting Discrimination of Sedimentary Basins. Contrib. mineral. Petrol. 92, $181-193$.

Bhatia, M. R., 1983. Plate Tectonics and Geochemical Composition of Sandstones. Journal of Geology, 91, pp. 611-627.

Bolarinwa, A. T., Idakwo. S. O. and Bish, D. L. 2019. Rare-Earth, Trace Element, and Hydrogen and Oxygen Isotopic Composition of Cretaceous Kaolinitic Sediments from the Lower Benue Trough, Nigeria: Provenance, Depositional and Paleoclimatic Significance. Acta Geochim. https://doi.org/10.1007/s11631-019-00328-y.

Bostrom, K., 1973. The origin and fate of ferromanganoan active ridge sediments. Stockholm contributions in geology, 27, 149243.

Bracciali, L., Marroni, M., Pandolfi, L. and Rocchi, S., 2007. Geochemistry and petrography of Western Tethys Cretaceous sedimentary covers (Corsica and Northern Apennines): From source areas to configuration of margins. Geological Society of America Special Paper, 420, 73-93. 
Burke, K. C., Dessauvagie, T. F. J., and Whiteman, A. J., 1971. The opening of the Gulf of Guinea and the Geological History of the Benue Depression and Niger Delta. Natural Physical Science, 233 (38), 51-55.

Chen, B., Liu, G., Wu, D., and Sun, R., 2016. Comparative study on geochemical characterization of the Carboniferous aluminous argillites from the Huainan Coal Basin, China. Turkish Journal of Earth Sciences, 25, 274-287.

Condie, K. C., Boryta, M. D., Liu, J. and Quian, X., 1992. The origin of khondalites: geochemical evidence from the Archean to Early Proterozoic granulitic belt in the North China Craton. Precambrian Research, 59, 207- 223.

Condie, K. C., 1993. Chemical Composition and Evolution of the Upper Continental Crust: Contrasting Results from Surface Samples and Shales. Chemical Geology, 104, 1-37.

Cullers, R. L., 1994a. The chemical signature of source rocks in size fractions of Holocene stream sediment derived from metamorphic rocks in the wet mountain region, Colorado, USA. Chemical Geology, 113, 327-343.

Cullers, R. L., 1995. The controls on the major and trace element evolution of shales, siltstones and sandstones of Ordovician to Tertiary age in the Wet Mountain region, Colorado, U.S.A. Chemical Geology, 123, 107-131.

Cullers, R. L., 2002. Implications of elemental concentrations for provenance, redox conditions, and metamorphic studies of shales and limestones near Pueblo, CO, USA. Chemical Geology, 191(4), 305-327.

Cox, R., Lowe, D. R. and Cullers, R. L., 1995. The influence 385 of sediment recycling and basement composition on evolution of mudrock chemistry in the southwestern United. States. Geochimica et Cosmochimica Acta, 59, 29192940.

EL-Wekeil, S. S. and Abou El-Anwar, E. A ., 2013. Petrology, geochemistry and sedimentation history of Lower Carboniferous shales in Gebel Abu Durba, southwestern Sinai, Egypt. Journal of Applied Sciences Research, 9 (8): 47814798.

Englund, J.O. and Jorgensen, P., 1973. A chemical classification system for argillaceous sediments and factors affecting their composition. Geol. Stockholm Forh. 95, 87-97.
Fatima, S. and Khan, M. S., 2012. Petrographic and geochemical characteristics of Mesoproterozoic Kumbalgarh clastic rocks, NW Indian shield: implications for provenance, tectonic setting, and crustal evolution. Int. Geol. Rev. 54 (10) 1113-1144.

Fedo, C. M., Nesbitt, H. W. and Young, G. M., 1995. Unravelling the effects of potassium metasomatism in sedimentary rocks and paleosols, with implications for paleo-weathering conditions and provenance. Geology, 23, 921924.

Floyd, P. A. and Leveridge, B. E., 1987. Tectonic environment of the Devonian Gramscatho basin, south Cornwall: framework mode and geochemical evidence from turbiditic sandstones. Journal of the Geological Society London, 144, 531-542.

Floyd, P. A., Winchester, J. A. and Park, R. G., 1989. Geochemistry and tectonic setting of Lewisian clastic metasediments from the early Proterozoic Loch Maree Group of Gairloch, NW Scotland. Precambrian Research, 45: 203-214.

Gromet, L. P., Dymek, R. F., Haskin, L. A., and korotev, R. L., 1984. The North American shale composite. Its compilation, major and trace element characteristics. Geochimica Cosmochimica Acta 48, 2469-2482.

Gu, X. X., Liu, J. M., Zheng, M. H., Tang, J. X. and Qt, L., 2002. Provenance and Tectonic setting of the Proterozoic turbidites in Hunan, South China: Geochemical Evidence. Journal of Sedimentary Research, 72, 393-407.

Hayashi, K., Fujisawa, H., Holland, H., and Ohmoto, H., 1997. Geochemistry of $\sim 1.9 \mathrm{Ga}$ sedimentary rocks from northeastern Labrador, Canada. Geochimica et Cosmochimica Acta, 61, 41154137.

Hallberg, R. O., 1976. A geochemical method for investigation of paleo-redox conditions in sediments. Ambio Special Report, 4, 139-147.

Isayeva, B.A., (1971) Relation between titanium and iron in the sediments of the Ocean. Geokhimiya, 3, 310-317.

Jones, B. and Manning, D. A. C., 1994. Comparison of geochemical indices used for the interpretation of paleo-redox conditions in ancient mudstones. Chemical Geology, 654 111, 111-129.

Le Bas M. J., Le Maitre R. W., Streckeisen, A. and Zanettin, B., 1986. A chemical classification of volcanic rocks based on the total alkali-silica diagram. Journal of Petrology, 27, 662 745-750. 
Levinson, A. A., 1974. Introduction to Exploration Geochemistry, Applied Publishing, Illnois.

Li, D., Li, R., Zhu, Z. and Xu, F., 2018. Elemental characteristics of lacustrine oil shale and its controlling factors of paleo-sedimentary environment on oil yield: a case from Chang 7 oil layer of Triassic Yanchang Formation in southern Ordos Basin. Acta Geochimica, 37(2), 228-243.

Liu, B., Y. Wangb, X. Sua and H. Zheng., 2013. Elemental geochemistry of northern slope sediments from the South China Sea: Implications for provenance and source area weathering since Early Miocene. Chemie der Erde, 73, 61-74.

Long, X., Yuan, C., Sun, M., Xiao, W., Wang, Y., Cai, K. and Jiang, Y. 2012. Geochemistry and Nd isotopic composition of the Early Palaeozoic flysch sequence in the Chinese Altai, Central Asia: Evidence for a northward-derived mafic source and insight into $\mathrm{Nd}$ model ages in accretionary orogen. Gondwana Research, 22, 554-566.

Machhour L., Philip J. and Oudin J. L., 1994: Formation of Laminite deposits in anaerobic dysaerobic marine environments. Marine Geology, 117, 287-302.

Madhavaraju, J., Ramirez-Montoya, E., Monreal, R., Gonzalez-Leon, C. M., Pi-Puig, T., EspinozaMaldonado, I. G. and Grijalva-Noriega, F. J., 2016. Paleoclimate, paleo-weathering and paleo-redox conditions of Lower Cretaceous shales from the Mural Limestone, Tuape section, northern Sonora, Mexico: Constraints from clay mineralogy and geochemistry. Revista Mexicana de Ciencias Geologicas, 33(1), 3469148.

McLennan, S. M., 1989. Rare earth elements in sedimentary rocks: influence of provenance and sedimentary processes. Rev. Mineral. 21, 170199.

Mclennan, S. M. and S. R. Taylor, 1991. Sedimentary rocks and crustal evolution: Tectonic setting and secular trends. Journal of Geology, 99, 1-21.

Mclennan, S. M., Hemming, S., McDaniel, D. K., and Hanson, G. N., 1993. Geochemical approaches to sedimentation, provenance, and tectonics. Processes controlling the composition of clastic sediments (Johnson, M.J. and Basu, A., eds.), 21-40, Geological Society of America special paper 284 .

Mikes, T., Dunkl, I., Eynatten, H. and Frisch, W., 2006. Geochemistry of Eocene flysch sandstones in the NW External Dinarides. Acta Geologica Hungarica, 49(2), 103-124.
Mishraa, P. K., AnkitbY., Gautamc, P. K., Lakshmidevi C. G., Singh, P. and Anoop, A., 2019. Inverse relationship between south-west and north-east monsoon during the late Holocene: Geochemical and sedimentological record from Ennamangalam Lake, southern India. Catena, 182, $104-117$.

Moosavirada, S. M., M. R. Janardhanab, M. S. Sethumadhava, M. R. Moghadamc and M. Shankaraa 2010. Geochemistry of lower Jurassic shales of the Shemshak Formation, Kerman Province, Central Iran: Provenance, source weathering and tectonic setting, Chemie der Erde.

Moosavirada, S. M., Janardhanab, M. R., Sethumadhava, M. S., Moghadamc, M. R. and Shankara, M., 2011. Geochemistry of lower Jurassic shales of the Shemshak Formation, Kerman Province, Central Iran: Provenance, source weathering and tetonic setting. Chem. Erde 71: $279-288$.

Mortazavi, M., Moussavi-Harami, R., Mahboubi, A. and Nadjafi, M., 2014. Geochemistry of the Late Jurassic-Early Cretaceous shales (Shurijeh Formation) in the intracontinental Kopet-Dagh Basin, northeastern Iran: implication for provenance, source weathering and paleoenvironments. Arabian Journal of Geosciences, 7, 5353-5366.

Murat, R. C., 1972. Stratigraphy and paleogeography of the Cretaceous and Lower Tertiary in Southern Nigeria. In Dessauvagie, T. T. J. and Whiteman, A. J. (eds.) African Geology. University of Ibadan Press, Ibadan, Nigeria, 251-266.

Nagarajan, R., Madhavaraju, J., Nagendra, R., Armstrong-Altrin, J. S. and Moutte, J., 2007. Geochemistry of Neoproterozoic shales of the Rabanpalli Formation, Bhima Basin, Northern Karnataka, southern India: implications for provenance and paleoredox conditions. Revista Mexicana de Ciencias Geologicas, 24, 150-160.

Nesbitt, H. W. and Young, G. M., 1982. Early Proterozoic Climates and Plate Motions Inferred from Major Element Chemistry of Lutites. Nature, 299, 715-717.

Obaje, N. G., 2009. Geology and mineral resources of Nigeria. Springer-Verlag Berlin Heidelberg. $221 \mathrm{p}$.

Obaje, N. G., Wehner, H. and Scheeder, G., 2004. Hydrocarbon prospectivity of Nigeria's inland basins from the viewpoint of organic geochemistry and organic petrology. American Association of Petroleum Geologists Bulletin, 88, 325-353. 
Odoma, A. N., Obaje, N. G., Omada, J. I., Idakwo, S. O and Erbacher, J., 2015. Mineralogical, chemical composition and distribution of rare earth elements in clay-rich sediments from Southeasthern Nigeria. Journal of African Earth Sciences, 102, 50-60.

Ojo, O. J and Akande, S. O., 2009. Sedimentology and depositional environments of the Maastrichtian Patti Formation, southeastern Bida Basin, Nigeria. Cretaceous Research, 30, 1415-1425.

Ojo, S. B. and Ajakaiye, D. E., 1989. Preliminary interpretation of gravity measurements in the Mid-Niger Basin area, Nigeria. In Kogbe, C.A. (Ed.), Geology of Nigeria, 2nd edn, Lagos, Elizabethan Publishers. pp. 347-358.

Okunlola, O. A. and Idowu O., 2012. The geochemistry of claystone-shale deposits from the Maastritchian Patti formation, Southern Bida basin, Nigeria. Earth Sciences Research Journal 16.2: 57-67.

Overare, B., Osokpor, J., Ekeh, P.C., Azmy, K., 2020. Demystifying provenance signatures and paleodepositional environment of mudrocks in parts of south-eastern Nigeria: Constraints from geochemistry. Journal of African Earth Sciences, doi: https://doi.org/10.1016/ j.jafrearsci.2020.103954.

Pettijohn, F. J., 1957 Sedimentary Rocks, 2nd edition. Harper and Row, New York. 628p.

Ramachandran, A., Madhavaraju, J., Ramasamy, S., IL Lee, Y., Rao, S., Chawngthu, D. L. and Velmurugan, K. 2016. Geochemistry of Proterozoic clastic rocks of the Kerur Formation of Kaladgi-Badami Basin, North Karnataka, South India: implications for provenance. Turkish Journal of Earth Sciences, 25, 126-144.

Roaldset, E., 1978. Mineralogical and chemical changes during weathering, transportation, and sedimentation in different environments with particular references to the distribution of Yttrium and lanthanide elements, Ph.D. Thesis, Geol. Inst., Univ. of Oslo, Norway.

Roser, B. P., and Korsch, R. J., 1986. Determination of tectonic setting of Sandstone and Mudstone suites using $\mathrm{SiO}_{2}$ content and $\mathrm{K}_{2} \mathrm{O} / \mathrm{Na}_{2} \mathrm{O}$ ratio. Journal of Geology, 94, 635-650.

Roy, P.D., Caballero, M., Lozano, R. and SmykatzKloss, W., 2008. Geochemistry of late quaternary sediments from Tecocomulco lake, central Mexico: implication to chemical weathering and provenance. Chem. Erde Geochem. 68: 383-393.
Rudnick, R. L. and Gao, S., 2003. The Composition of the Continental Crust, In Treatise on Geochemistry, Elsevier - Pergamon, OxfordLondon, 3:1-64.

Saccà, C. D., Saccà, P., Nucera and Fazio, A. D., 2011. Composition and geochemistry of clay sediments offshore the northeastern Sicilian coast (Southeastern Tyrrhenian Sea, Italy). Estuarine, Coastal and Shelf Science, 92, 564572.

Suttner, L. J. and Dutta, P. K., 1986. Alluvial sandstone composition and paleoclimate, Framework mineralogy: Journal of Sedimentary Petrology, $56,329-345$.

Taylor S. R, McLennan S. M. 1981. The composition and evolution of the continental crust: rare earth element evidence from sedimentary rocks. Philosophical Transactions of the Royal Society london A 301:381-399.

Taylor, S. R. and S. M. McLennan, 1985. The Continental Crust: Its Composition and Vietnam in the western South China Sea: Implications for source analysis and East Asian monsoon evolution. Science in China Series D: Earth Sciences, 50, 1674-1684.

Turekian, K. K. and K.H. Wedepohl 1961. Distribution of elements in some major units of Earth, Crust. Geol, Soc. Amer. Bull., 77(2): 175-195.

Willan, R. C. R., 2003. Provenance of TriassicCretaceous sandstones in the Antarctic Peninsula; implications for terrane models during Gondwana breakup. Journal of Sedimentary Research, 73, 1062-1077.

Wronkiewicz D. J. and Condie K. C., 1987. Geochemistry of Archean shales from the Witwatersrand Super group, South Africa: Source area weathering and provenance. Geochimica et Cosmochimica Acta, 51, 24012416.

Wronkiewicz, D. J. and Condie, K. C., 1990. Geochemistry and mineralogy of sediments from the Ventersdorp and Transvaal Super groups, South Africa: cratonic evolution during the early Proterozoic. Geochimica et Cosmochimica Acta, 54, 343-354.

Zaid, S. M., 2012. Provenance, diagenesis, tectonic setting and geochemistry of Rudies sandstone (Lower Miocene), Warda Field, Gulf of Suez, Egypt. J. Afr. Earth Sci. 66-7, 56-71.

Zaid, S.M. and Al Gahtani, F., 2015. Provenance, diagenesis, tectonic setting, and geochemistry of Hawkesbury Sandstone (Middle Triassic), southern Sydney Basin, Australia. Turkish Journal of Earth Sciences, 24, 72-98. 